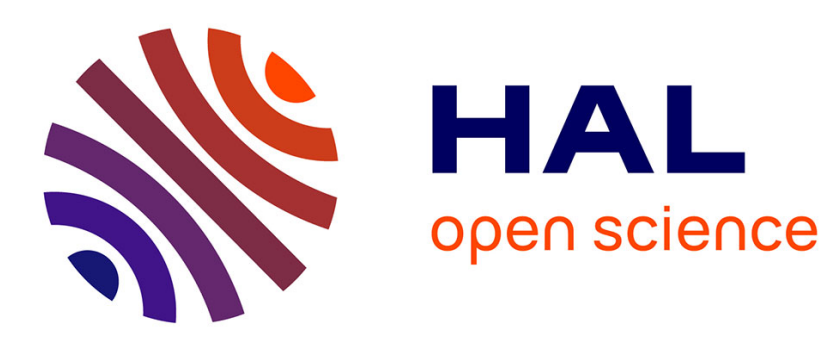

\title{
Stones against the Iron Fist, Terror within the Nation: Alternating Structures of Violence and Cultural Identity in the Israeli-Palestinian Conflict
}

Scott Atran

\section{To cite this version:}

Scott Atran. Stones against the Iron Fist, Terror within the Nation: Alternating Structures of Violence and Cultural Identity in the Israeli-Palestinian Conflict. Politics and Society, 1990, 18. ijn_00000567

\section{HAL Id: ijn_00000567 \\ https://hal.science/ijn_00000567}

Submitted on 25 Jan 2005

HAL is a multi-disciplinary open access archive for the deposit and dissemination of scientific research documents, whether they are published or not. The documents may come from teaching and research institutions in France or abroad, or from public or private research centers.
L'archive ouverte pluridisciplinaire HAL, est destinée au dépôt et à la diffusion de documents scientifiques de niveau recherche, publiés ou non, émanant des établissements d'enseignement et de recherche français ou étrangers, des laboratoires publics ou privés. 
Stones against the Iron Fist, Terror within the

Nation: Alternating Structures of Violence and

Cultural Identity in the Israeli-Palestinian

Conflict

\section{SCOTT ATRAN}

\section{INTRODUCTION: STRUCTURES OF VIOLENCE}

The framework of the Israel-Palestinian Arab conflict has evolved over the last half century through an instrumentalization of violence by the parties concerned. Two alternating "structures of violence" have emerged to define this instrumentality: the one Israeli, the other Palestinian.

I call these structures of violence "alternating" rather than merely "reciprocating" because the one not only feeds off the other and actually practices on the other that which is merely fancied and projected as the other's intention but also because they have inverse periodicities: The "Great Revolt" (al-Thawra alKubra) of 1936-1939 introduced the principle of "armed struggle" (al-kifah al-musalah) into the practice and lore of a fractured and often factional antiBritish and anti-Zionist insurgency. It was effectively countered by British might coupled with an essentially defensive Jewish posture of consensus and "restraint" (havgalah). By contrast the current Palestinian "Uprising" (Intifada) has the Arab side preaching restraint if not always nonviolence (al-la 'unf), through a pluralistic consensus on the immediate national ends such practice aims to achieve. Against this is an avowed Israeli policy of "the iron fist" (ha-yad hazaqah, barzel Yisrael) that for the first time since independence has broken the general Zionist consensus with regard not only to the utility and morality of violent means but also to national goals.

Both structures have a threefold character: (1) a material goal, the path to which, if it is perceived to be blocked, is judged a proximate cause for violence; (2) institutional modes of violence that delimit the scope and limits of its application, and (3) a moral imperative that defines the ethics of violence for whom and to whom it may be applied and under which circumstances it may be necessary or counterproductive. The joint articulation of these three components can be deemed an "ideology of violence." It is with the elaboration of such ideology, including its irrational and mystical underpinnings, that this article is concerned. My hypothesis is that for different reasons both sides initially lacked such ideologies-and therefore also lacked structures of violence-then proceeded to elaborate them in tandem. The dominant ideologies, however, were not elaborated asmirror images of one another but in a somewhat refractory and inverted way.

There is, it appears, a "tension" that develops and structures these alternating ideologies of violence. Driven by the essentialist logic of an inherently unstable nationstate identity, it compels victim and victimizer to internalize and invert the other's ideology. The increasingly marginalized victims institutionalize their violence as one means of centralizing their cultural claim to a homeland while victimizers morally co-opt the victim's image. There are degrees and phases in this alternation. Peace could be one of them. 


\section{THE MATERIAL GOAL OF VIOLENCE}

In its concrete expression, the material goal is much the same for both sides: a sovereign national territory in (and ideally over) historic Palestine. Much more than the quest for markets or labor, the struggle for an exclusive territory is the material factor that fuels both national movements. Acquisition of land is considered the primary mode of national "redemption." Thus it is hardly surprising that "land" is the central metaphor in the Zionist-Palestinian struggle. The first Zionist colonizers referred to Palestine simply as "The Land" (Ha-aretz), and this is the familiar way Israelis call their country. For Palestinians historically, "land and honor" (al-ard wal- ard) were inseparable values and worthy of life and death struggle (even religion generally did not carry such practical commitment). The first organized party of political resistance for Palestinians within Israel was the soon-outlawed "Land Party." Presently, "Land Day," which initially marked the death of Israeli Arabs protesting over continued Government seizure of their lands in March 1976, is considered by Palestinians both within Israel and in the Occupied Territories as the premier annual event that unites them in resistance to Zionist expansion. Even Israelis are compelled to recognize Land Day as the Arabs' unofficial "national day." 1

Mutual perception of these virtually exclusive territorial claims emerged gradually between the period of initial colonization and World War I. ${ }^{2}$ From the outset of the British occupation, Jewish leaders refused to acknowledge that the majority population of Arab peasants had any claim or tie to the land. According to Zionist leader Aaron Aaronson:

The fundamental point to be remembered was that the fear of expropriation did not come from the fellahin, who possessed very little land, but from the Effendi class, who obtained the land by doubtful means .... It was evident that .... the fellah had no land. ${ }^{3}$

As for the effendis, their land should be bought or seized. But rather than giving some of it over to the fellahin, Britain should award it to Jewish settlers who know how to build up the largely "desert and derelict" country.

By the war's close, Zionist planners were calling for the transfer of "the fellah tenants of the effendis" out of Palestine. ${ }^{5}$ Representatives of the Muslim and Christian Arab communities in Palestine warned the American King-Crane Commission, which was sent by Wilson in the name of the Paris peace conference, that if the Jews come they will try to push "us back to the Hedjaz [Arabian desert]" and "this country will become a river of blood." Zionist commentators interpreted the Arabs to mean: "[W]e will push the Zionists into the sea-or they will send us back into the desert." ${ }^{6}$ The Zionist leadership opposed any democratic powersharing arrangement with the Arabs on the grounds that: "With very few exceptions the Fellahin are illiterate and would be entirely under the influence of the few literate Effendis and their agents." In the end, Chaim Weizmann, head of the Zionist Organization, persuaded British Prime Minister David Lloyd George to instruct Colonial Secretary Winston Churchill: "You mustn't give representative government to Palestine." 8

Nevertheless, the anti-Jewish riots of May 1921 compelled the British high commissioner for Palestine, Herbert Samuel, a confessedly "moderate" Zionist, to insist that Churchill allow Arabs representation in a "legislative assembly" that would act in an 
advisory capacity to the Civil Administration. A census of the country was instituted in 1922 for the purpose of preparing a list of electors. Despite the apparent willingness of some members of the Arab Executive to participate in the election scheme, however, the Palestinians ultimately rejected any power-sharing arrangement that would deny them majority control-to the great relief of the Zionist Executive. ${ }^{9}$

Regardless of Zionist and British assurances that Jewish political and territorial claims were not exclusive, high-ranking Jewish leaders consistently told their colleagues on the Palestine Zionist Executive (and later Jewish Agency Executive) that "there is not enough room in the country for both peoples." ${ }^{10}$ According to the Zionist Labor Organization, widespread Arab rioting in 1929 against the Jewish settlement (Yishuv) resulted not, as a British Government Commission owned, ${ }^{11}$ from threat of dislocation and dispossession. Rather Arab violence was instigated by "the intrigue of the clique of effendis," which incited "the fanatical instincts of the ignorant Arab masses."Any Arab claim to self-determination was worthless since it came either from blood-sucking effendis or peasants and proletarians who have "no representation in the true sense of the term.... The Arab populace thus remains inarticulate, and their life interests practically unvoiced." ${ }^{12}$ If Arab sentiment were properly voiced, it would undoubtedly reflect what "every resident [of Palestine] is forced to recognize," namely, wealth, progress, peace and "the development of common ties among all sections of the population."13

But again the British floated the idea of a Legislative Assembly, arousing fear in the Zionist leadership that the Arabs would thereby effectively obtain a veto over any expansion of the Jewish settlement. ${ }^{14}$ And again, despite some guarded Palestinian approval of the idea, the Arab Executive ultimately rejected any elective participation in a government that failed to overturn Britain's mandatory commitment to a "Jewish National Home in Palestine." ${ }^{15}$ In contrast to Palestinian Arab insistence on an immediate and definitive institutionalization of "majority democratic rule," the Zionists did not publicize their intention to establish a Jewish state in Palestine (aside from Jabotinsky's increasingly marginalized Revisionists). Instead, they focused on the incremental achievement of a social, political, military, and territorial infrastructure that was well on the way to securing them "economic-strategic" control of the country by the outbreak of the Arab revolt in $1936 .{ }^{16}$

By 1938 with the Arab Revolt in full swing, Ben Gurion and the majority of the executive were calling for the removal of "Arab tenants, laborers and farmers from the Jewish State to neighboring Arab states" in accordance with the British Royal Commission's suggestions for a population transfer. Nor did Ben Gurion exclude the possibility that the transfer would have to be carried out by an "iron fist" (yad hazagah). ${ }^{17}$ Nevertheless although Ben Gurion and other Jewish Labor leaders imagined the eventual likelihood of Zionist sovereignty over all of historic Palestine with the aid of "an elite army ... one of the best in the world, ${ }^{18}$ during and after the Arab revolt they did accept the notion of a provisional territorial compromise. By contrast, Jabotinsky's Jewish nationalist Revisionist Party rejected anything less than full sovereignty over the biblical land of Israel. At the very least, this implied "an iron wall" (ha-qir ha-barzel), ${ }^{19}$ that would exclude Arab nationalist aspirations from Palestine and Transjordan.

For the most part, mainstream Israeli leaders, whether of the left or right, have consistently argued that Palestinian Arabs are incapable of representing themselves much less worthy of a territory of their own. Indeed, as late as 1969, Labor leader Golda Meir 
denied "there was a Palestinian people in Palestine considering itself as a Palestinian people... . They did not exist." ${ }^{20}$ While current Labor leaders Shimon Peres and Yitzhak Rabin still do not grant Palestinians the right to choose the PLO as their representative, they do allow today that some expression of "Palestinian national rights" may be legitimate. Many leaders of the right, however, still take the view of Yossi Ben Aharon, Director-General of the Prime Minister's Office:

We should treat this population according to the customs and standards of an Arab society. We speak of Palestinian "opinions" but it should be remembered that there is no Arab government which is a government of the people, for the people ... what is a Lebanese, a Coptic Egyptian, and Iraqi Kurd? These are not nation-states in the classical sense of the word. This wall-to-wall Palestinian coalition which seeks self-determination should not be taken to seriously .... If you look at the whole complex, you must reach the conclusion that the PLO is not a liberation movement. They have succeeded in this big deception, and many Israelis have fallen for it, that there is such a thing as Palestinians... . But from the point of human rights ... you agree to some sort of modus vivendi... They will accept this .... I believe this is realistic.... With an Arab society it can be done. We give life, they know how to give death. ${ }^{21}$

Except for the Palestine Communist Party, the idea of a Palestinian state in Gaza and the West Bank alongside Israel did not appear on the Palestinian nationalist agenda until shortly before the October 1973 war. ${ }^{22}$ But this would merely represent a "stage" on the way to total liberation of historic Palestine. It was not until nearly a year after the outbreak of the Intifada that the PLO accepted the principle of an internationally secured territorial compromise. Now, however, Yasser Arafat, chairman of the PLO Executive, has declared caduque (null and void) ${ }^{23}$ those aspects of the Palestinian National Charter that consider: "Palestine, within the boundaries it had during the British Mandate, an undivided territorial unit" (art. 2) and "an indivisible part of the Arab Homeland" (art. 1) to the exclusion of Jews born after "the Zionist invasion" (art. 6). ${ }^{4}$ In counterpoint, Israeli Prime Minister Yitzhak Shamir, head of the nationalist Likud coalition, replies that talk of trading territories for peace is treife (nonkosher) and that "an 'iron fist' would meet any bid for a Palestinian State." ${ }^{25}$ In this, Shamir follows the policy of his predecessor, Menahem Begin. For it was Begin who, as Jabotinsky's heir, inaugurated Likud's triumph over Labor and its ascension to power in 1977 with a policy of "Israel's iron" (barzel Yisrael) that aimed to right the historic wrong of the 1948 United Nations partition of Palestine: "The partition of the Homeland is illepl.... Eretz Israel will be restored to the people of Israel. All of it and forever." ${ }^{26}$

Today all public opinion polls indicate that the idea of "Greater Israel" is accepted by the majority of Israel's population, although perhaps half the country is still open to the idea of negotiating "peace for territory." Increasingly, however, with the rising popularity of the Israeli radical right, the public approves of the idea that the Palestinians have no place in their country. Although as yet only a small minority is willing to support the program of Rabbi Meir Kahane's Kach (Thus) Party, which calls for the expulsion of practically all gentiles (goyim) from the holy land, three relatively new parliamentary parties, which form part of the governing coalition, openly advocate removal of the Arabs from Greater Israel: Tehiya (Renaissance), which calls for "repatriation" of Palestinians to other parts of the Arab world, Tsomet (Crossroads), which advocates a "population exchange" of Palestinian Arabs for the remaining Jews in Arab countries, and Moledet (Homeland) whose campaign symbol is "T" for an offer of "transfer" that the Palestinians will surely "agree upon" someday. In addition, some kind of "demographic solution" is an 
avowed aim of the ultranationalist wings of the Nationalist Religious Party (NRP), Shas (ultraorthodox party of Sephardic Jews) and Likud 27 To the degree that these parties appear to be intent on implementing their "solution" to the Israel-Palestine conflict, Palestinians argue, the current Uprising cannot be wholly nonviolent after all, goes the comparison, the British Raj never intended to evict Gandhi and his people from India.

\section{INSTITUTIONAL MODES OF VIOLENCE}

While intermittently violent conflict over territorial claims characterized JewishArab relations in the period between the Arab revolt and the end of World War II, the two communities still had not developed ideologies of violence. Only with the advent of the "memory of the Holocaust" did Zionists assert a moral imperative to employ violent means for the wholesale departure of the Arab population from part of Palestine and for the necessity of denying Palestinians a sovereign national territory of their own. Although before that time Zionists largely adhered to ethnocentric notions of Arab "backwardness" and "bloodthirstiness," they were generally uninterested in adopting the "civilizing mission" of the imperial powers or the socialist international. This was because of the Jews' own involvement in a struggle for national liberation and because they fundamentally did not seek the labor, markets, or salvation of the Palestinian Arabs.

By contrast, the Arabs were armed with a moral imperative that seized on popular stories of the Assassins and wars against the crusaders by invoking the tradition of the fida iyin and the notion of struggle that involved sacrifice 28 A prominent form of "radical traditionalism" involved the followers of Shaykh 'Izz al-Din al-Qassam and his nationalistic brand of Islamic revivalism (salaftya). It was they who initiated the principle of sustained "armed struggle" that Al-Fath was to consciously resurrect 30 years later, ${ }^{29}$ and that, after the outbreak of the Intifada, the Islamic Resistance Movement (Hamas) enshrined in its covenant (of 18 August 1988). Unlike the secular Fath, however, the Qassamites saw themselves as fighters (mujahidin) in a holy war (jihad). Tinged with religious fervor, the moral imperative for violent struggle also invoked a confused mixture of anti-imperialism and antisemitism. Jewish lust for money and blood as evinced in such works of "historical fact" as The Jewish Peril and Protocols of the Elders of Zion required a strategy of offense to defend everything truly dear to human beings. In addition, Jewish "Bolshevism" sought to destroy God-fearing family and community life: "You bring with you people who are Bolshevik Disciples, you bring with you dangerous Thieves, Impostors and all sorts of Filth from Europe, while you profess that you are bringing civilization." 30

What the Palestinian Arabs lacked, however, was the means to permanently structure their violent opposition to Zionism. They did not have a coherent political framework for carrying through a revolutionary program of national liberation even remotely comparable to Zionism's largely autonomous and autarchic protostate apparatus. ${ }^{31}$ Commentators of whatever political persuasion surmise about the revolt that the insurgents failed to institute a coherent political program because they failed to acquire the trappings of a modem revolutionary party and a policy for progressive political action. ${ }^{32}$

Although the peasants acted in part out of revolutionary motives, theirs was primarily a "reactive struggle" akin to that of the sans culottes before the Jacobin state 
took form. It was an intensely defensive struggle, continuous and with a long history of popular rebellions that mark the period before the "proactive" movements of a consolidated capitalist economy and nation-state: that is, an effort to reclaim traditional rights and to uphold standards that they believed were imperiled by the innovations of capitalists, speculators, agricultural "improvers," or government functionaries. ${ }^{33}$ In the end, this popular struggle collapsed because it remained essentially populist, nonprogrammatic and limited in its autonomy and power to develop a revolutionary program by the lingering hold of the nahiyeh sheikhs and the domination of the effendiyat and ayan (that is, a declining landed gentry, an emergent bourgeoisie, and a rising class of urban-based religious notables). ${ }^{34}$

In the current Palestinian uprising, resurgent echoes of the Qassamite tradition are heard from militants of the Gaza-based Jihad al-Islami, a splinter group of the Moslem Brotherhood that preaches holy war against the Jews as "a Moslem duty." The idea that Israel, Judaism, and Jews challenge Islam also forms part of the covenant of Hamas, the military arm of the Brotherhood; but it is Israel and Zionism, rather than Jews and Judaism per se, that are damned for "Nazi treatment" of "men and women, children and old people": "The Zionist invasion is a vicious one.... It aims at undermining society, annihilating Islam, and it is behind the drug trade and alcoholism in all its kinds." ${ }^{35}$ It is to the most disadvantaged elements of Palestinian society that such radical Islamic fundamentalism readily appeals: especially to those in Gaza's squalid refugee camps who comprise the majority of the strip's population. After decades of degrading social, economic, and political privation in one of the most densely populated hells on earth. they have little to lose and less to look forward to. They are thus willing to offer life and limb, which is all that is left to them. In the marginally less desperate West Bank refugee camps, pan-Arabist (PFLP) and MarxistLeninist (DFLP) notions of "revolutionary violence" vie for popular support and control with Hamas's call to take up "the sword for Islam. "36 But it is the PLO's dominant faction, Fath, with broad-based support among the youth and large middle classes both within the Occupied Territories (fil-dakhil) and outside (fil-kharij), that provides a "bottom line" for unity of the Palestinian national movement: namely, independence in (at least part of) historic Palestine.

According to political scientist Yezid Sayigh: "It is Fateh's success in rebasing itself in the Occupied Territories [following the 1982 Lebanese debacle] that has preserved its centrality in the Palestinian national movement as a whole and reinforced its hold on PLO decision-making." ${ }^{37}$ Its focus on international diplomacy appeals to many intellectually and economically influential Palestinians resident in the West while its changing emphasis from clandestine military action to social and political activity in the Territories has made it the preeminent force among local Palestinians. One reason for this was the activity of Khalil Wazir (Abu Jihad), Fath's principle coordinator for action in the Occupied Territories. Before his expulsion from Amman in May 1986, Wazir was able to build a dynamic youth movement (Harakat ash-Shabibah) in the territories that, while not eschewing military action, favored sociopolitical mobilization: student and women's organizations, medical and agricultural relief committees, trade unions, and so forth. Before the Intifada, the Shabibah were able to organize large demonstrations against the occupation and to mobilize their cadres to coordinate and eventually dominate the spontaneous outpouring of protest following the outbreak of the Intifada in December 
1987. Arguably, Wazir's assassination in Tunis by Israeli commandos in April 1988 not only failed to undermine Fath's operational capability but also critically reinforced the Shabibah's stature and role in the uprising.

True, Fath and the Shabibah initially neither controlled nor guided the weekly actions or immediate goals initiated by the local leadership of the Unified Command of the Intifada. But with repeated success by Shin Bet (Israel's general security services) in dismantling the successive replacements of the youthful command structure, local leadership at the national level began to lose its depth and flexibility. Increasingly, the Unified Command's biweekly leaflets (manashir), which periodically established the uprising's protocols, were dictated directly from PLO headquarters in Tunis. Lost was the Unified Command's ability to initiate on-the-spot changes in national policy such as restraining the spread of violent action to Israel proper and emphasizing civil disobedience over armed struggle in an attempt to force Israel to parlay rather than succumb. By the end of the Intifada's first year, however, local initiatives had largely been absorbed into PLO thinking while Fath's diplomatic offensive on the international front offered the only hope that the army's increasing success at rooting out and controlling the level of local resistance would not doom the Intifada in its unequal match against Israeli military, economic, and administrative might.

The popular committees in each town, village, and camp also eventually fell under the control of the Shabibah and the hundreds of former security prisoners (released in 1985 for six Israeli soldiers in a deal brokered by Ahmed Jebril's non-PLO splinter faction, PFLP-General Command). At the outset, the popular committees sought mainly to provide medical care and social services to Palestinians hurt in the uprising. In addition, the aid committees set about reorganizing local commerce, agricultural production, and education in order to locally sustain the Unified Command's calls to strike and boycott Israeli goods and to compensate for Israel's closing of Palestinian schools.

From the start, the Shabibah's organizational know-how provided an infrastructure for the aid committees. But these local civilian-support groups also drew upon qualified professionals, students, workers, and housewives from virtually every walk of life who had evinced no history of active participation in any political organization. Although at first tolerated by the Israelis, their aid to the injured and their "do-it-yourself" tactics came to be regarded by th-, security services as abetting the enemy and fostering civil disobedience. Forced underground in August 1988, the popular committees soon transformed into local operational commands of the Unified Command, directed by the experienced cadres of Fath's Shabibah and former security prisoners of the other PLO groups (especially PFLP and DFLP). Still it was the shotgun wedding of spontaneous civilian support to the PLO's post-1982 organization in the Occupied Territories that has institutionalized local coordination of the uprising and maintained a national mobilization of the people.

There is another significant factor in the formation of a Palestinian national ideology and institutional framework and in the transformation of the accompanying ideology of violence from "armed struggle" to "techniques of resistance," including "nonviolence." This factor is the example of the Israeli nation-state, which has spurred Palestinians in general and the PLO in particular to gradually adopt those forms of pluralistic democracy that could best assure the coordinated survival of its diverse 
constituents. ${ }^{38}$ In fact, there are striking similarities between the manner in which Fath established its hegemony over the PLO by inviting the participation of politically diverse resistance groups in the late 1960s and early 1970s and the manner in which Zionist Labor (Mapai) established its hegemony over the Jewish settlement (Yishuv) in mandatory Palestine. ${ }^{9}$ Plausibly the Zionist example served as something of a model for the Palestinian organization, although their respective trajectories indicate an inverse, rather than a direct, relation: Once Labor established hegemony in the Zionist movement and opened the ranks of the Jewish Agency and its executive to include religious and nationalist groups, it changed its main priority from "building socialism" to building a state." After statehood, advancement to positions of political responsibility were no longer predicated on social service but primarily on service in the state bureaucracy and the military. By contrast, a guerrilla background is no longer a sine qua non for advancement in the middle ranks of the PLO (the upper ranks being still reserved for the "founders") and "civilian" personalities are coming to occupy increasingly prominent positions in the Palestine national movement ${ }^{41}$

Like Zionist Labor, Fath's predominance within the national movement owes more to its main action on behalf of the concrete task of nation building from within than on behalf of a commitment to pannational alliances or ideologies. But Zionist Labor, in its conversion from a movement of social construction and mobilization to military and bureaucratic "statism," has left its waning legacy of state power to nationalist elements. In order to maintain a national consensus, these elements rely increasingly on a symbolic justification for the organization of force-whether that force be considered "defensive" (by most Israelis) or "coercive" (by most Palestinians)-rather than on a centralizing commitment to a common social program. By contrast, Fath's ability to forge a national consensus depends less than ever on its military role and more on success at merging its diplomatic, administrative, and social services with the PLO structure as a whole. This arguably provides a common outlet of political expression for diverse elements of the Palestinian community both within the territories and throughout the world. As a result, potential violence between disaffected elements within the community may be appreciably lessened while violence against the common enemy can be calculated and coordinated to achieve the widest reasonable gain (international pressure on Israel to force recognition) at lower cost to life than a shooting war. ${ }^{42}$

It is especially within the ranks of "mainstream" Fath, that policy decisions reflect a conscientious attempt to avoid a repetition of the failings of the revolt and the ensuing "catastrophe" (Nakba) of 1948. Criticism of the means and goal of the Thawra thus constitutes a significant factor in the emergence of an increasingly pluralistic and consensual Palestinian ideology of struggle. Indeed, the Thawra operates as the Intifada's primary model and foil in this respect. As Palestinian political analyst Elias Sanbar notes:

If the means of struggle form an historical continuity-the permanence of certain social rules, of certain techniques [of resistance], of a certain memory of past collective struggles-the Intifada cannot thereby be reduced to being a successful 'remake' of that other aborted revolution. The differences, the originality, are profound and not only with respect to the period, the means, the processes of resistance, but especially the vision and political targets that the present movement has fixed. ${ }^{43}$

Under a different interpretation, reflection on the revolt also determines aspects of Israeli appreciation of the uprising. According to Hebrew University 


\section{professor of family law Ze'ev Falk:}

The record of the PLO both against Israelis and Jews as well as against Arabs is well known. During the intifada as well as during the Arab Revolt of 1936-39 the Arabs killed and wounded more Jews than Arabs and created a terror regime similar to that of Lebanon ... people accused of collaboration, leaders who venture to express an independent view, laborers violating one of the continuous strikes and many other Palestinians are being attacked, wounded and killed by the henchmen of the PLO and Hamas. ${ }^{44}$

The Intifada, like the Thawra before it, is thus proof-positive of the "medieval ethos" of Arab fanaticism and militarism, which would make a Lebanon of Israel should the Jewish state cede to Palestinians seeking "equity" through "unsuitable means" that "should not be in a liberal democracy. ,45

Israeli profiles of the adolescent stonethrowers-the violent "front line" of the Intifada-stress the alienation of Palestinian youth from their own society. Arab culture, it is argued, places a strong emphasis on values such as courage and dignity for males. These subcultural values define certain circumstances and stimuli that appropriately evoke physical aggression, especially on the part of young Palestinian males who are generally unemployed and out of school. In this vein, following an impassioned appeal to Palestinians to "keep the children out of the war," Ze'ev Falk is pessimistic that his appeal will be heeded given the "medieval social ethos" of young Palestinian stonethrowers: ${ }^{46}$

Unfortunately for Arab children and for Arab nations in general, the disregard of children's interests is a result of stagnation and lack of cultural development. The social ethos of Arab society is still in its medieval stage of militant Islam. Hence the fighter stands at the apex of the social pyramid, and the child chooses stonethrowing to achieve recognition. Instead of seeking success in various directions of cultural development, Arab society is still caught up in honor, pride, glory and similar values of medieval militarism. $^{47}$

Italian judge Domenico Gallo, however, offers a quite different appreciation of who is keeping the children hostage to war.

Who actually makes a cynical use of Palestinian children? Don't you think closing the public schools, forbidding private lessons, even forbidding the UNRWA [United Nations Relief and Works Agency] ... to distribute to the children didactic material, is just like symbolically taking all the children as hostages to hit the Palestinian people in what is most sacred to them and to any other people: the love of their children. ${ }^{48}$

Palestinian analysts tend neither to stress inherent values nor hardship as the principle motivation for stonethrowing. While they acknowledge that Arab cultural values are indeed distinct from Israeli values, such values do not directly condone or require violence. Rather violent behavior is a product of the way social structural conditions-in particular politically determined conditions-limit the expression of these values. ${ }^{49}$ Violent forms of collective protest (of which stonethrowing is perhaps the most frequent and ritualized example) are considered to arise more out of a conscious engagement in the struggle for political expression, ${ }^{50}$ than because of frustrated socioeconomic expectations. ${ }^{51}$

It is this tenacious denial of the Palestinians as a people that enables Israel to believe it can successfully impose a colonization and ultimately succeed in overseeing docile inhabitants content to hew the wood and till the soil remaining them, while buying television sets and washing machines. However, it 
is the Palestinians' insistence upon their identity as a people that, barring the mass population transfer to neighboring states called for by growing numbers of Israeli extremists, dooms Israel's efforts to ultimate failure. $^{52}$

From this vantage, stonethrowing is a controlled political act meant to "show the world and especially Israeli citizens that the [national] movement constitutes a menace for the Israeli occupation but not for Israel itself within the frontiers of

1948-49." ${ }^{53}$

But it is on the symbolic plane that the ritualized medium of stonethrowing most strongly evokes the Intifada's relations of continuity and change with the Thawra. The stones cast, mostly by young men born and bred under Israeli occupation, are interpreted in the chants and poems of the Intifada (azjal) as parts and voices of the dismembered motherland. As such, the stones are endowed with an almost mystical force to overpower the bullets launched by the iron fist. This force does not operate exclusively in the material realm but more significantly in a realm close enough to the material to have a physical impact and closer still to that of the communication media where the war will ultimately be won or lost. The militant core of stonethrowers is largely perceived, both by Palestinians and Israelis as rooted in the refugee camps. The camps, composed mainly of sundered families uprooted from areas lying within Israel's pre-1967 borders, have become the true "villages" of today's Palestine, and the interconnected organizations of young refugees now constitute the real "families" of the nation.

Unlike the Thawra's peasant fellah, the Intifada's young shabab has little material connection to the soil yet has succeeded in conceptualizing an organic tie between land and nation that appreciably overrides the cleavages of religion, class, and clan that plagued the earlier revolt: "[D]o not ask me my party or religion, I am of the soil of this land and my name is ' arabi falastini" (an Intifada zajal). In the emerging lore, these young people of the Intifada are imagined by themselves and by their elders as the budding "flowers" and stoutly maturing 44 live trees" of the land. To the western media's criticism: "[H]ow can parents send their children out to face injury or die?", the response is one of honor and pride: "[W]e protect our motherland from further violation and from the dishonor inflicted on her children-our brothers and sisters-by their dispossession and disenfranchisement. We are the descendants of the disappeared fellahin-their avengers and redeemers."

The question is whether the spiraling cycle of violence between the army, their collaborators and the stonethrowers will destroy the delicate balance between "politics," symbolism, and physical violence in favor of the latter. Israeli military leaders acknowledge that the Intifada represents the popular uprising of a whole nation that cannot be subdued with anything like the techniques of repression currently being used. Either the army would have to increase the level of violence by orders of magnitude, or a "political solution" will have to be found. ${ }^{54}$ Still, the fact is that the level of military violence shows little sign of ebbing in the third year of the Intifada. Although the number of Palestinians killed by the army fell by more than half in the first four months of 1990 from the nearly 100 killed in the first four months of the preceding year, the massacre of 7 Palestinian workers by a lone Israeli gunman, and the subsequent killing of an equal number of protesters by the army on the same day demonstrated to many in the Israeli military and the press that: "a single event suffices to provoke an explosion [because] the basic conditions that are at the origin of the Intifada have not only failed to 
have been eradicated but have worsened. "55 Indeed "for the first time since 1967 riots and strikes encompassed the entire Arab population living under Israeli control," including violent Arab Israeli demonstrations in Nazareth. ${ }^{6}$ Fundamentalist extremists on both sides were quick to mobilize in the cause of violence as Israel and Arab countries talked of the increased likelihood of generalized war. Although violence again ebbed over the summer months, the killing in October by Israeli police and border guards of over a score of Palestinian demonstrators on Jerusalem's Temple Mount was the bloodiest single event of the Intifada to that date. Symbolically and politically, it was also the most portentous. ${ }^{57}$ Rather than attempt to calm passions, the Israeli government simply and (according to Israeli journalist Ze'ev Schiff) quite falsely claimed that the violence had resulted from a premeditated Iraqi-PLO plot to undermine the U.S.-led anti-Iraq coalition. Moreover "to block further violence, the Israeli army kept Palestinians in the occupied territories confined to their homes" while advertising in Israel's major newspapers to exhort "Jews to gather at the Wailing Wall ... in a show of defiance against the Arab stoning attack that prompted the violence." ${ }^{58}$ In such an atmosphere, it is hardly surprising that few Israelis or Palestinians doubt that more violent times are ahead.

With regard to future attitudes and actions of youth toward violence. according to a poll sponsored by the Israeli Ministry of Education, there is an alarming trend among the next generation of Israeli soldiers: 40 percent of current Jewish high school students "hate all, or almost all, Arabs." ${ }^{59}$ Among young Palestinians too, the forecast is ominously clouded. Increasingly, youth are involved in attacks on "collaborators." The first acknowledged killing of a collaborator occurred in February 1988, three months after the outbreak of the Intifada (after he shot to death a four-year-old). Imprisoned nationalist leaders even organized clandestine political indoctrination courses in their jails to preach against reprisals on informers. By summer 1989, however, "collaborators" were being killed with greater frequency and less discretion. Increasingly, common prostitutes, drug users as well as peddlers, and others who would betray the moral "purity" of the Intifada were being shot and stabbed to death, burned and buried alive, decapitated or otherwise eliminated. ${ }^{60}$

Israelis and Palestinians blame one another for the brutalization of their respective societies. But whereas the present Israeli administration seems prepared to maintain and even increase the level of violence as the struggle goes on, the dominant factions of the PLO-plausibly with the lessons of the Thawra in mind and in consideration of the Western media-have appeared to be making a concerted effort to reign in the use of "revolutionary justice" and even emphasize wholly nonviolent forms of civil disobedience, such as nonpayment of taxes. ${ }^{61}$ Nevertheless, without movement on the international political-diplomatic front, it is hard to see how renewed emphasis on nonviolent civil disobedience can effectively counter the foreboding chant of the disaffected youth of Gaza, Nablus, and Jenin: "Abu Ammar (Arafat's nom de guerre) patience has run, your people revolt, wanting a gun" (Abu Ammar, as-sabr rah, sha'abak tha'er, bidu slah). ${ }^{62}$

\section{THE MORAL IMPERATIVE}

Whatever the pragmatic, rational, and instrumental relation between (1) the 
material goal and (2) the institutional means, that relation is based on a fictional reality that is an inherent part of (3) the moral imperative, which irrationally grounds the whole structure of violence. ${ }^{63}$ From the Jewish side, the relation of Israeli society to the Palestinians is stamped with "a deeply-rooted existential fear, which lives on a very particular interpretation of the Holocaust, such as the readiness to believe that the whole world is against us and we are the eternal victims." ${ }^{64}$ Accordingly, virtually any violence against them can be condoned in the name of Israeli "national security," which is considered the moral equivalent of the Jewish people's desperately unending struggle for survival against nearly impossible odds. As OC Northern Command Major-General Yossif Peled stresses, the army's role is to see Israel free by keeping the guard up against the Arab threat, that is, the threat of extermination: "[W]e have to be strong to deal with all eventualities, remembering what our people have gone through and the six million who died." ${ }^{65}$ For only Israel is the plausible victim of genocide.

Palestinians living in the territories controlled by Israel now frequently allege that they are victims of "genocide"... Yet ... only Israel is a plausible victim of impending genocide. Although the Arabs in the West Bank and Gaza face an increasingly harsh "iron fist" response to the intifada, it is only the Jews of the region who face annihilation.

Using the paradoxical logic of the Holocaust motif, Israel thus claims its right to be a virtual superpower in the Third World because of its victimization by the First World. Within this perspective, Israel's brutal "iron fist" against the Palestinians is trivialized while Palestinian violence is magnified to potentially monstrous, "impending" proportions. The fact that, since independence, Israeli Jews have killed far more Palestinian Arabs than Palestinian Arabs have Israeli Jews can thus be laid to a justified principle of disproportionate retaliation. ${ }^{7}$ In this regard, increasingly large segments of the the Israeli army and public no longer shy from the rallying cry of ultranationalist poet and ideologue Uri Tsvi Greenberg who wrote during the Arab Revolt in 1937:

Double blood for blood. Double fire for fire ... for thus races repay their enemies; across generations and throughout time .... A country is conquered in blood ... from thz River of

Egypt to the Euphrates. ${ }^{68}$

As Moledet party leader Rehavam Ze'evi ranted on the floor of the Knesset: "Every Jew is worth a thousand Arabs" (kol yehudi shaveh elef aravim) $6^{9}$ From this slant, even extreme measures can seem a barely adequate response to the neo-Nazi menace. ${ }^{70}$ Charges of brutality are thus curtly dismissed as vestiges of European ignorance-if not covertly antisemitic relishing-of the Jewish plight: For example, Amnesty International reports of Israeli paramilitary death squads, summary executions, and "the wide range of human rights violations by Israeli forces since the outbreak of the intifada." ${ }^{71}$ For Israel in fighting Palestinians is up against Nazi surrogates and their apologists.

The fundamentalist fusion of messianic aspirations of redemption and apocalyptic visions of failure, which proves generally congenial to Israel's dominant party in government, the Likud, thus allows a ready transference of th;, memory of the Nazidriven holocaust to current reality. Within this framework, Israel Eldad, the intellectual guru of the Israeli radical right, justifies the assassination of PLO leaders along the lines, say, that "Abu Jihad ... was none other than a Palestinian version of Eichmann." ${ }^{2}$ In the same vein, Prime Minister Shamir (Likud) has compared Yasser Arafat's recent peace 
overtures to the "time in the 1930s when Hitler was celebrated the world over as some kind of savior....They belong to the same family of totalitarians, enemies of the Jewish people, men who think nothing of killing millions to achieve their objectives." For Defense Minister Moshe Arens (Likud), European contacts with Arafat are thus reminiscent of Western appeasement of the Nazis. ${ }^{3}$ According to Housing Minister Ariel Sharon, any peace overture by the PLO is thus ruled out in advance.

Suppose, for a moment, that after the extermination of millions of Jews, Adolf Hitler, old and tired from so much fighting, offers to the State of Israel to negotiate peace and war reparations. Is it imaginable that we would negotiate with him? ${ }^{74}$

In this way are the six million "nationalized." 75

\section{Nationalization of the Holocaust}

Although today, the memory of the Holocaust (or Shoah in Hebrew) furnishes perhaps the chief stock of centralizing symbols for Israeli identity and national consciousness, this was not always so. Except for the immediate aftermath of World War II, when Zionism needed the silent support of European Jewry's murdered masses to counter British and Arab opposition to statehood, the Holocaust was virtually ignored by Israeli writers and politicians throughout the 1950s. For the Labor party, the dominant force in Zionism since the 1930s and the principal architect of the state, the Holocaust symbolized almost everything in Jewish relationships with the world that Zionism aimed to replace. The Holocaust, argued Labor leader and Prime Minister David Ben Gurion, "represented past events in foreign countries, the sad memories of Jews in exile, but not the affective experiences and events of life that instruct and guide us." ${ }^{76}$ Indeed the overriding "imperative of the Jewish revolution" was "to break radically" with the Diaspora (Galut): "Galut means dependence-material, political, spiritual, cultural, and intellectual dependence-because we are aliens, a minority, bereft of a homeland, rootless and separated from the soil, from labor, and from basic industry. ${ }^{177}$ At this stage then, the moral of the Holocaust was that the better part of Jewish life and history should be forgotten. Unconvinced on this score, most Jews have continued the option of extending that history in the Diaspora.

From Labor's vantage, the symbolism and memory of the Holocaust served primarily as Zionism's foil: the young, secular, laboring, and creative pioneers of the new Israel, with their "elite" army, would "master our fate," "take our destiny into our own hands," and "create, by our own effort, the necessary conditions for our future." When, in 1954, the Labor Government established Yad Vashem ("the Place and the Name," Isaiah 56:5) as an institution "to commemorate the Holocaust and Heroism," the governors of the young state meant the focus to center on "heroism," rather than on the millions sheepishly brought to slaughter. A national day for the commemoration of the Holocaust was chosen to coincide with the anniversary of the most defiant act of physical resistance to the Nazis: the Warsaw ghetto uprising. The slogan "never again" was taken to mean that this atypical example of the Diaspora's courage and prowess would henceforth become a commonplace part of the moral character of young Israel. Holocaust Day was thus symbolically interjected (though hardly remembered in public ceremony) in the two weeks of collective celebration and national contemplation between Passover and Independence Day-between the first and second Exodus to freedom. 
By the end of the 1950s, Israel's immigration and growth began to stagnate and rising Arab nationalism again threatened its security. The capture in 1960 by the Israeli secret services of Adolf Eichmann, principal coordinator of Hitler's "final solution," marked a new stage in the Israeli construction of national identity through the memory of the Holocaust. The first true "media event" in Israeli history, the Eichmann trial broke a tacit conspiracy of silence about the Holocaust's victims and the remnants of the Diaspora. It seemed geared to permit a haltingly maturing Israel to reestablish contact with the Jewish past and the world outside in order to derive renewed sustenance from both. Still, there was little attempt to go beyond describing the litany of Nazi atrocities and the helplessness of their victims. Few Israelis paid heed to Gershom Scholem's open leader in defense of Hannah Arendt's Eichmann in Jerusalem, which refused to countenance Zionist intimations that Hitler's victims tacitly "collaborated" in their own execution by the simple fact of their living in exile rather than choosing exodus. ${ }^{78}$

The exuberant Israeli victory of June 1967 again reduced the significance of the Holocaust's service to the state. But following the traumatic near-defeat of October 1973, the Holocaust began to acquire a fresher and more acrid national and international character. From the mid-1970s on-with immigration, growth, and the socialist mission for national construction stagnating and Palestinian resentment over occupation risingIsrael's post-Ben Gurion generation of governing Labor bureaucrats began the insidious process of dubbing any Palestinian guerrilla action "terrorism." This dubbing was intended to secure internal and external support for the state on three grounds. First, by manipulating the centralizing logic of the nation-state to marginalize Palestinians as potential "terrorists," political representation could be denied them; their land could be more readily alienated; their houses, destroyed; and their children, prevented from returning home. ${ }^{9}$ The weakening Labor government could then legitimize colonization of the Occupied Territories before world opinion on the simple basis of "national security," although even Labor "doves," like Abba Ebban, acknowledged to their local audience that extension of the Jewish "homeland" beyond its pre-1967 "Auschwitz lines" was a more primary consideration. ${ }^{80}$ Second, by then embedding discourse on terrorism in the centralizing cold war rhetoric of the western alliance, Palestinian terrorists could be stigmatized as the agents of a monolithic "communism" intent on world hegemony-a view congenial to the United States' bipolar vision of the world at the time. ${ }^{81}$ Third, by assimilating communist-sponsored terrorism to attacks against the moral person of a state that claimed to represent the Holocaust's survivors, Palestinians could be thus transformed into would-be nazis before the eyes of the world. ${ }^{82}$

With the ascent to power of Menahem Begin and the nationalist right, the inverted equation of Palestinian opposition with the terror of the Nazi state became total: "In the Land of Israel we are condemned to fight with all our soul. Believe me, the alternative is called 'Auschwitz'. We are determined to do everything to prevent another Auschwitz. "83 "From this perspective," notes Idith Zertal, "it is not a formidable army that penetrates Lebanon, in the midst of a civilian population, to confront a handful of Palestinian terrorists, but a handful of survivors that go out to avenge Auschwitz and build a new order where the vanquished become conquerors and weakness makes strength." ${ }^{84}$ Holocaust Day, too, is transformed from a mere passing note in the interval between the two great Zionist homecoming festivals. A somber national ceremony with a heavy military aura, its negative tones now drown out the fading clarion of Labor's 
hollow call to form a nation united in social purpose. ${ }^{85}$ The definitive response to Hitler's "final solution" to the Jewish problem becomes the "state Zionism" preached by the nationalist heirs of Vladimir (Ze'ev) Jabotinsky's prestate revisionist movement: "Revisionism sees the aim of Zionism as providing a complete and final solution of the Jewish world-problem in all its aspects....For the purpose just described, the territory of Western Palestine alone is not sufficient." 86 In the moral logic of the secular Israeli right then, greater Israel is the answer to Auschwitz.

Given this moral framework, the outbreak of the Intifada and the rise of Palestinian violence has led to a disproportionate Israeli reaction. What were once considered extremist (or even "crackpot") proposals just before the Intifada have now become commonplace policies increasingly acceptable to the Israeli mainstream. For example, days before the outbreak of the Intifada, Gideon Altschuler, a founding member of Tehiya, advocated that Arab stonethrowers, including children, be dealt with by issuing shoot-to-kill orders. ${ }^{87}$ Not only have such orders been issued, but soldiers are now permitted to fire live ammunition at masked youths even if they are not armed, throwing stones, or engaging in any overtly hostile action. ${ }^{88}$

Israelis not only fear their adversary but also create through their very selective 'memory of the Holocaust' confusing images of "terrorists" and "terror." This ultimately leads Israelis to practice on Palestinians that which is fantasized and feared about Palestinians on Palestinians. ${ }^{89}$ Thus during unsettled situations, Israeli settlers may bash in the heads of Arab adolescents or set fire to Arab fields without fear of punishment 90 On the contrary, the army simply absolves itself from responsibility with "warnings that Israeli soldiers may no longer be able to control Jewish civilians." ${ }^{91}$ Indeed when settlers rampage, it is the victims who are punished with curfews whose violators may be shot on sight: "An army spokesman said Israeli troops were not responsible.... He said the army clamped a curfew on the village of 3000 to aid its investigation. It was the worst incident in a recent outbreak of vigilante reprisal raids by Jewish settlers on Arab communities." 92 Given the government's "iron fist" policy of "force, power and blows," even "manifestly illegal orders" to beat unarmed suspects "whether resisting or not" that lead to a suspect's death are not judged to be really "illegal" after all; rather they come under "gray areas" for soldiers in the field that "result in part from the complexity of the situation." 93 Consider that when four soldiers of the Givati Brigade where charged in the torture and death of a Gaza refugee camp resident, the military court dismissed the manslaughter account on the grounds that, after seven hours of being kicked, punched, beaten with a broomstick, and so forth, it was impossible to determine "who struck the fatal blow." Nevertheless "there is no doubt that the man died of violent beatings by soldiers. This must shock any civilized or moral person who values life," the decision said. Arguably, persistence of the underlying Holocaust motif thus runs the risk of rendering "Humanistic Judaism" a mere rhetorical apology for unbridled acts of brutality.

By generalizing the role of Nazi victimizer to those fighting its policies, Israel's "Holocaust credit" in the West is gradually lost. Trivialization of the role of victimizer also prompts a corresponding banalization of the role of victim. In this regard, Palestinians argue that they too are victims of Nazism-not only indirectly through the United Nations decision to compensate Jewish victims of World War II with part of Palestine but directly through Israel's use of "Nazi tactics" and 'racist violence." ${ }^{95}$ Israelis see the comparison as grotesque and a further indication of Palestinian immorality. Only 
they fail to see that "the original sin of ideologically instrumentalizing the 'memory of the Holocaust' was committed by the Jewish-Israeli collective. "96 Unfortunately rather than debunking the ideologized "memory of the Holocaust," often Palestinians have further distorted it in ways that immunize it from any critical analysis and deprive humanity of its unparalleled moral force. In this Palestinian use of the Holocaust motif to imagine the evil culture of their adversary, Israel finds its own worst fears confirmed.

As these moral musical chairs are repositioned, each side's victimizer is immorally perceived as a Nazi and therefore the would-be victimizer righteously perceives himself as an avenging victim. The only way out of this macabre game it appears is to forget "the memory of the Holocaust" without forgetting the Holocaust itself. ${ }^{97}$ But however reasonable or desirable such a course would appear, in fact the flame of that abusing memory is being fanned to ever more portentious heights by the violent spiritual and physical clash between the Intifada and the Israeli radical right ${ }^{98}$

\section{Messianic Nationalism and the Holocaust Motif}

On the Israeli radical right, the Holocaust motif is embedded in a messianic faith that the Jews are compelled to reconquer and thus sanctify the biblical land of Israel in the manner of Joshua and King David. From a Zionist standpoint, national redemption differs from other struggles for national liberation in that political liberation has to be preceded by a return to the homeland of Zion. Jews can only realize their historic mission to redeem the soul of their nation and thereby act as "a light unto nations" (la-goyim) through total spiritual communion with, and physical domination of, the whole biblical land of Israel. Although socialist Labor Zionism exhibited messianic overtones, its criteria for national redemption were essentially those of the universalist and rationalist movements of the European enlightenment and Jewish haskalah: reason, science, technical achievement, liberalism, and humanism. That the Arabs of Palestine did not subscribe to such "progressive" aims was only proof of their "backwardness," not their wickedness. For the radical Zionist right, however, Jews are driven down the road to national redemption by essentially romantic and metaphysical notions that abhor the metallic hollowness of modernism and the weak and decadent liberalism of the West. ${ }^{99}$ While many on the radical Israeli right do not altogether reject the Israeli state's principles of democratic pluralism and the secular rule of law, most are willing to subordinate those principles to the quest for a "greater Israel" and to advocate the use of extralegal means to thwart any perceived attempt to compromise that quest; for "democratic Zionism" implies that democracy is in the service of Zionism and not the other way around. ${ }^{100}$ Needless to say, Palestinian Arabs who do not subscribe to Zionism, have no claim to democratic rights in Israel.

The leading light of the Israeli radical right, whether secular or religious, is the wide coalition of forces known as Gush Emunim (Block of the Faithful). Like Hamas, the radical Islamic fundamentalist movement, Gush Emunim maintains that God did not mean Palestine to be divisible. Although the coalition began to form following Israel's "inspired" victory in the 1967 Six-Day War, it did not coalesce until Israel was "chastised" by the Yom Kippur War of 1973 for letting the guard down against Gentiles bent on preventing the final redemption of the Jewish people. It is arguably "the most effective social movement that has emerged in Israel since its 1948 establishment". ${ }^{101}$ Just as the concrete achievements of the kibbutz movement in mandatory Palestine 
helped propel the Labor party to dominance within the Zionist movement, nowadays it is the pioneering settlements of Gush Emunim that appear to an increasingly large Israeli public as most incarnating Zionism's positive program of spiritual redemption through colonization of the soil. ${ }^{102}$ As such, it provides the concrete foundation of socioeconomic achievement for a whole spectrum of right-wing parties that the nationalist (Revisionist) party of mandatory days so notoriously lacked, including: Tehiya, Tsomet, Moledet, and the ultranationalist wings of Likud, Shas, and the National Religious Party.

Regarding the Arab-Israeli conflict, Gush policy proceeds from the premise that: "Arab hostility springs, as does all anti-Semitism, from the world's recalcitrance in the face of Israel's mission to save it." ${ }^{103}$ Its message to the Palestinians is unambiguousforsake all political rights over any part of Israel, or forsake the right to live in Israel.

If the advice of the evil counselors-your PLO and our Peace Now-is carried out, and Israel withdraws from the West Bank, you know that in a few years your extremists will takeover and inflict another war on this country. An Israeli army which will have to conquer Nablus, Hebron and Jericho again and shed blood for them again-will it leave a single Arab in the West Bank? ${ }^{104}$

To be sure, the position of Gush Emunim and its many sympathetic supporters on the radical Right was not always so extreme. Shortly following the unexpected completeness of victory in June 1967, which enlarged territory under Zionist domination threefold, a very large cross-section of Labor's ruling elite, the leftist intelligentsia, and remnants of the nearly-forgotten nationalist right formed a movement (Ha-tenua le ma' an Eretz Yisrael) for the permanent retention and settlement of the conquered territories. The Land of Israel Movement (LIM) of August 1967 was the broadest coalition in Zionist history. Among its adherents were Jabotinsky's son, Eri, ultranationalist ideoloques Israel Eldad and Uri Tsvi Greenberg, future Nobel laureate S.Y. Agnon, and followers of Yitzhak Tabenkin (founder of Labor's most dynamic kibbutz movement, Hakibbutz Hamiuhad). It also enlisted the sympathy of many members of Ben Gurion's splinter Party, Rah, (including war-hero Moshe Dayan) which had split from the dominant Labor party, Mapai after Ben Gurion left power. ${ }^{105}$ Arabs were urged to participate with Jews in reclaiming the territories long neglected as backwaters under Egyptian and Jordanian rule.

By the end of the decade, however, the movement's lack of an activist political program, coupled with the withdrawal of Begin and the "classical Right" from the Labordominated national unity government formed during the 1967 crisis, prompted Eldad and others to begin the process of politicization and radicalization of the "Greater Israel" camp. ${ }^{106}$ By 1973, LIM's successor, "Labor for the Whole Land of Israel," was squarely allied with Begin's newly formed Likud. The 1973 Yom Kippur War, although a military victory for Israel, was a psychological disaster, and the Israeli public's faith in the Labor leadership was severely shaken. In 1974, the growing number LIM activists were comparing Labor Prime Minister Yitzhak Rabin's acceptance of ("self-hating Jew") Kissinger's limited -erritorial compromise with Egypt and Syria to Chamberlain's appeasement of Hitler at Munich in 1938. ${ }^{107}$

In March 1974, Gush Emunim was established, in part to resist further territorial concessions. Although initially a wing of Labor's ally, the National Religious Party (NRP), Gush soon dissociated itself with all other movements including LIM. Its aim in doing so was to avoid "politics" and concentrate on settling the Occupied Territories. In 
this, its chief tactical inspiration was Moshe Levinger, a former kibbutz rabbi. Shortly after the Six-Day War, Rabbi Levinger had defied Dayan, the Army, the Arabs, and a hostile press by illegally squatting in the West Bank city of Hebron in Judea, site of the 1929 Arab massacre of (mostly non-Zionist, religious) Jews. This set the pattern for the media confrontation between Labor's limited "settlement for security" policy and the maximalist settlement designs of Gush, supported by Likud's large parliamentary opposition and growing public constituency. Even with Labor still in power, Gush won the right to settle in the heart of Hebron and in Samaria's Nablus region.

The euphoria of Begin's stunning election triumph in 1977, which ended half a century of Labor dominance in the Zionist movement, soon gave way to near-despair when, at Camp David in September 1978, Begin agreed to give the Sinai back to Egypt. Now it was Begin who was compared to Chamberlain. ${ }^{108}$ Gush began mobilizing support against additional territorial concessions, inciting a split in the ranks of Likud and the NRP and encouraging the formation of a new political party, Tehiya. Although Gush failed to prevent withdrawal from Sinai despite considerable effort, its actions traumatized and further radicalized the nationalist right. Begin was compelled to begin implementation of Gush's ambitious 1978 settlement program, which called for 100,000 Jews in the Occupied Territories within a decade. With the 1982 War in Lebanon looming, Begin invited Tehiya into the government and placed its founder and Israel's most renowned nuclear physicist, Yuval Ne'eman, at the head of the Ministry of Science and the government's Settlement Committee. Had it not been for Labor's brief return to power in 1984-1986, the current figure of more than 80,000 settlers would surely have been surpassed and Gush's target reached.

The radicalization of Gush's position on the Arab question-and with it the position of the entire radical right-owes to a variety of factors. Foremost, perhaps, is the rise of the PLO and the sense of Palestinian nationalism among the Arabs of both Israel and the Occupied Territories. Israeli-Arab Land Day in March 1976, when six Arabs were killed and many more of Arabs and Israeli policemen were injured, convinced many Israeli Jews that either all Palestinian Arabs were PLO at heart or that no accommodation with the Arabs was possible without the annihilation of the PLO. In addition, by the early 1980s, the deteriorating Israeli economy was leading to increased racial friction between Arabs and (typically Sephardi) Jews inhabiting urban slums and stagnant development towns who refused to further lower their standard of living to compete with cheap Palestinian labor. To the disgruntled, Gush offered generous terms for housing and employment in the Occupied Territories with hundreds of millions of dollars in settlement funds. ${ }^{109}$ But the aggressive Gush settlement policies in densely inhabited Arab areas caused Arabs to fear their imminent expulsion, and they responded aggressively in kind.

With rising Arab incidents of throwing stones and Molotov cocktails and especially with the May 1980 shooting and death of six Jewish Yeshiva students in Hebron, Gush activists began organizing terrorist attacks against selected targets (including the crippling of the mayors of Nablus and Ramallah) and vigilante raids against Arab villages. Gradually they began drawing closer in sympathy and act to the extreme anti-Arab program of Rabbi Meir Kahane, which included eviction of Arabs from the land of Israel and destroying the Moslem religious "abomination" on Jerusalem's Temple Mount. ${ }^{110}$ In 1984, Israeli intelligence revealed the existence of a 
secret underground (machteret), apparently operating with the knowledge and at least tacit approval of Gush's "father of settlement," Moshe Levinger. The underground had planned to blow up five crowded Arab buses and earlier plotted to destroy the Moslem Dome of the Rock in order to scare the Arabs into leaving the country and to retake the area of Solomon's Temple for the coming Messiah. ${ }^{111}$ At first the disbelieving leadership of the Yesha Council, the primary settler organization in the West Bank, denied Gush involvement and hinted at a leftist conspiracy to discredit the movement. ${ }^{12}$ Yet not only did the evidence prove incontrovertible but also the principal protagonists vaunted their involvement. An embarrassing debate ensued within Gush ranks over the use of "countertenor" that was initially hostile to the underground. Most Gush Rabbis argued the opinion of their recently deceased spiritual guide, Rav Yehuda Tsvi Kook, who seemed to hold that the Israeli government and army were divinely vested with exclusive responsibility for the defense of the land of Israel. With the advent of the Intifada, however, an increasingly vociferous section of the movement opted to challenge the army's prerogative and bring their confrontational anti-Arab position out into the open, advocating "double blood for blood" and deportation of the entire Arab population of historic Palestine. ${ }^{113}$

Although most adherents to the Israeli radical right's advocacy of Greater Israel and Arab transfer are nonreligious, nearly 90 percent of Gush's activists are religious fundamentalists. ${ }^{114}$ Fundamentalism, unlike ultraorthodoxy, does not leave the turn of events to God alone or allow His flock to contemplate and execute His commandments in social or political isolation. Rather, God makes a pact with man, which promises redemption and salvation for humankind on the condition that His chosen executors actively see to it that His will is done. Fundamentalism, because it is commanded to implement divine truth, must be as politically committed as it is dogmatically intolerant and uncompromising in regard to any political opposition.

Most Gush members and many of their sympathizers follow the creed of messianic nationalism, that is, the redemption of greater Israel (Giulat Eretz Yisrael haShlaimah). ${ }^{115}$ In this worldview, Jewish existence has one essential purpose: to carry out the terms of the covenant between God and Abraham. 116 God's House, that is, the whole of Palestine (and perhaps parts of Lebanon, Syria, Jordan, Iraq, and Egypt as well), must be purified by His chosen servants so that humankind can be saved from evil. ${ }^{117}$ But first the land must be possessed:

To your descendants I give this land from the River of Egypt to the great river, the Euphrates. (Genesis 15:18)

You shall dispossess the inhabitants of the land and dwell therein, for I have given you the land to possess it. (Numbers 33:53f.)

Behold, the Lord your God has set the land before you: go up and possess it. (Deuteronomy 1:21)

Within fundamentalist ranks a debate rages as to whether "conquest of the land" (kibush haqarqa) takes precedence over the preservation of (Jewish) life (pikuach nefesh), that is, whether withdrawal from the Occupied Territories falls under the principle that a Jew should give up his life rather than allow the area to be ruled by gentiles (ye' horeg $v^{\prime}$ al ya'avor). Nevertheless, there is at least general agreement that Israel has an obligation to rule sovereign over the territories even if it means casualties, 
provided the military estimates that success is likely. ${ }^{118}$ According to Shlomo Goren, former Ashkenazi Chief Rabbi, war over any part of the land of Israel constitutes an "obligatory war" (milhemet mitzva). This is especially so for (the Occupied Territories of) Judea and Samaria-"the very heart of the Land":

when we have sovereignty over Eretz Yisrael and have the military power we are forbidden to permit non-Jews who are idolaters to live in Eretz Yisrael. Obviously, in order to achieve this goal we will have to exert force against them .... One might argue that the prohibition against "giving them lodging in Eretz Yisrael" does not apply to the Arabs, who are not idolatrous and whose monotheistic belief is unquestionable. This claim has no substance .... Our struggle against the intifada is in the category of an obligatory war which... is a super milhemet mitzva calling for mesirut nefesh-the utmost devotion. ${ }^{119}$

Those who would thwart realization of the divine pact between God, His land and His people-that is the neo-Edomite Christian powers and the neo-Amalekite Arab peoples-must be overcome and where possible destroyed: "Any framework or international organization whose resolutions imply the humiliation of the honor of Israel has no right to exist." ${ }^{120}$ The Holocaust has proven that socialist Zionism as well as the "traditional" Jewish nationalist right were sinfully wrong to suppose that western civilization rested on Judaic foundations. The Jewish Bible had barely penetrated the surface. It was Mr. Hyde's Kultur of the Third Reich, not Dr. Jekyll's siecle de lumidres, that expressed Europe's essential underlying nature. This evil nature had nearly destroyed the Jewish people, but had also blessedly killed off the Diaspora idea of emancipation through assimilation with the peoples of Europe. In the wake, Israel had risen through its war of independence like the phoenix, with its Jews both physically and spiritually resurrected. To Jewish fundamentalist eyes, this clearly was the culmination of the long cyclic history of divinely ordained catastrophe and miraculous deliverance. The final process of material redemption had begun (that of Meshiah Ben Yosef, Messiah the son of Joseph) and spritual redemption would soon be at hand (that is, Meshiah Ben David Messiah the son of David): "We are reliving the days of Joseph, Moses, Joshua and David all at once." 121

For secular ultranationalists, Zionism in fact constitutes the material process of redemption, and the Messiah of spiritual redemption is comprised of the whole Jewish people redeemed. They simply substitute a transcendental historicogeopolitical mission for the divine imperative. The religious communion between land and people is replaced by an organic synthesis of the settler with his homeland, and the question of humanity's salvation is left moot: "I don't believe that God said anything to Abraham. I see in the promised borders the geopolitical mission of the people of Israel for its generations... it doesn't bother me that they [the religious] believe their source is divine." ${ }^{122}$ Within the messianic ultranationalist spectrum, there may be disagreement over momentary or tactical accommodation with adversaries for the sake of eventually converting them if they are Jews or eliminating them if they are not. But world opinion generally is considered pernicious, and Western (particularly American) opinion is ultimately irrelevant, ${ }^{123}$ insipid, ${ }^{124}$ or baneful. Even the opinion of world Jewry is essentially of no consequence:

The Tehiya-Tsomet negates the Diaspora.... Every exile is bound, in the fmal analysis, to decline and perish, either as a result of assimilation and conversion or following persecution and even a future unavoidable holocaust. ${ }^{125}$ 
At their most visceral, secular ultranationalists amplify Rabbi Meir Kahane's religious diatribe against the anti-Jewish, effete, and degenerate notions of liberal democracy in Labor Zionism and western parliamentary tradition. ${ }^{126}$

In the final battle between good and evil-as Israel approaches its destiny to deliver up the whole house of God-the old siren-songs reappear in subtler and ever more beguiling discourse. In place of the Golden Calf, or European ideas of enlightenment and emancipation, have come American "liberalism" and "human rights." As for the Arab, at best he may be tolerated as an "alien resident" (ger toshav) of the Jewish people in Israel. ${ }^{127}$ At worse, he is the primeval Canaanite tribesman who, together with his children and womenfolk, were to be smitten for harassing the conquering Hebrews. $^{128}$

The only metaphysical and concrete alternative to ultimate Jewish victory is physical and spiritual annihilation of Jews and Judaism. The closer Israel comes to achieving its goal, the louder evil cries and the mightier it threatens. From this messianic and chauvinistic standpoint then, Israel's growing international isolation is perhaps the best indication that the forces of good are on the march. ${ }^{129}$ For, "[1]o, the people shall dwell alone, and shall not be reckoned among the nations" (Numbers 23:9):

A Sceptre shall rise out of Israel, and shall smite the comer of Moab, and destroy all the children of Seth.... And Edom shall be a possession, Seir also shall be a possession.... Out of Jacob shall come he that shall have dominion, and shall destroy him that remaineth of the city .... Amalek was the first of nations; but his latter end shall be that he perish forever.... Alas, who shall live when God doeth this! (Numbers 24)

For by fire and by his sword will the Lord plead with all flesh: and the slain of the Lord shall be many... and they shall declare my glory among the Gentiles. (Isaiah 66)

Accordingly, there is likely to be only one reasonable and "humane" outcome to the Israeli-Palestinian conflict that avoids annihilation of one or the other side. It is an outcome long contemplated by Zionist planners but never so urgently as by the Israeli radical right:

If we want to avoid unremitting bloodshed, there is only one solution-the transfer of the Arab population of the Land of Israel to the Arab states....This solution is a humane solution compared to the "final solution" which the Arab world plans for us. ${ }^{130}$

\section{CONCLUSION: TERROR AND THE CULTURAL IDENTITY OF THE NATION STATE}

Two things are necessary to a nation-state: a culture and a homeland. So at least has the modern nation-state often been conceived. For the community of nations generally and the Jews in particular, the "Jewish question" has been posed in both theoretical and practical terms to treat the conceptual "anomaly" of a people without a homeland. This anomaly has occupied world attention to an extent all out of proportion to more apparently rational economic, demographic, and strategic concerns. Even the unremitting religious tangle of reciprocal misunderstandings, which distorts the aspirations that the Christian and Moslem nations perceive in one another, does not 
account for the world's unusual political interest in an area the size of New Jersey with a population barely that of greater Philadelphia.

The conception that produces the problem is ontological, and the ontology is basically taxonomic. The cultures of the world, one presumes, naturally and exhaustively divide into mutually exclusive territorial homelands in which reside the essences of those cultures "as if the teleology of all social entities was the state. ${ }^{\circ} 131$ Cultures that do not so divide are therefore unnatural. The understandable confusions that arise between modern peoples then often translate into conflicts about where exactly the "natural" boundaries must lie. But confusion over the Jewish question represents the basic problem intrinsic to the essentialistic notion of the nation-state in a striking way. From the essentialist perspective, the Jews represent one people too many on the face of the earth. In the course of this century, three "final solutions"-imperative and categorical in conceptionhave been offered and partially implemented: assimilation to the fraternal brotherhood of all nations, extermination, and the ingathering of exiles in Zion.

After the failure of Germany's attempt to instantiate its vision of the nationstate and given the ever-present unlikelihood of a communist dissolution of the nation-state, the United Nations opted for the Zionist answer to the Jewish question. ${ }^{132}$ The answer was fundamentally that first proposed in 1896 by Theodor Herzl in Der Judenstaat (The Jewish State):

The Jewish Question exists. Where it does not exist it is dragged in by immigrating Jews. We naturally move to places where we are not persecuted; and by our presence the persecution comes about. This is true and must remain true everywhere, even in highly civilized countries-for instance, France-as long as the Jewish Question does not find a political solution....

It is a national question which can only be solved by making it a world-question to be dealt with by the civilized nations.... Palestine is our unforgettable historic home. The very name would be a force of marvelous potency for summoning our people together. ... For Europe we would form a portion of the rampart against Asiahere; an outpost of civilization as opposed to barbarism. ${ }^{133}$

But only Europe and to some extent, the United States, had ever supported this last proposition as a reason of state. ${ }^{134}$

Throughout its nearly one hundred years, a central premise of Zionism has been that Palestinians did not and could not constitute a culture in a truly "national" sense. For liberal Zionist leaders like Wiezmann, the Palestinians were simply part of an amorphous Arab mass located at the western frontier, whose "real" center lay elsewhere:

The problem of our relations with the Palestinian Arabs is an economic problem, not a political one. From the political point of view the Arab centre of gravity is not Palestine, but the Hedjaz, really the triangle formed by Mecca, Damascus and Bagdad." ${ }^{135}$

For Zionist Labor, Palestinians could have no national culture because they lacked (the ability to develop) sufficiently advanced forces of production. Accordingly, argued Ben Gurion, "we do not recognize their right to rule the country to the extent that it has not been built by them."136

Only the revisionist, or nationalist, camp in Zionism acknowledged the validity of Palestinian as distinct from pan-Arab-aspirations to nationhood and the incompatibility of those aspirations with Zionism. According to revisionism's founder, Ze'ev Jabotinsky: 
Their cultural standard is low, and they do not possess our endurance and willpower, but... they cling to the land of Israel, at least with the same instinctive love and primitive fanaticism displayed by the Aztecs to their Mexico or the Sioux to their prairies. To think that the Arabs will voluntarily consent to the realization of Zionism in return for the cultural and economic benefits we can bestow on them is infantile and has its source in a feeling of contempt which "Arabophiles" have for the Arab people...

If it was possible (and of this I am very doubtful) to convince the Arabs in Bagdad and Mecca that for them the land of Israel is no more than a small and unimportant frontier region, for the Arabs of the land of Israel it would not be so, but would remain their homeland, the center and basis of their national existence....

I am optimistically convinced ... that both peoples, like good neighbors can live in peace. But the only way leading to such an agreement is by "erecting an iron wall," meaning that in the land of Israel there must be a power that will not under any circumstances lead yield to Arab pressure. In other words, the only way to achieve an agreement with them in the future is by absolutely avoiding any attempts at agreement with them at present. ${ }^{137}$

From this vantage, if history required an association of nations that was necessarily exclusive at its founding, the Jews must be given a place and the Palestinians a choice: to assimilate to the other Arab nations or to accept cultural "autonomy" without the political rights that go with the territory. This choice initially did not appear as stark as that which the Jews seemed to be faced with (to be in Zion or not to be) but neither was it altogether of a different conceptual sort.

In Hegelian fashion, secular messianists allied to the revisionist movement saw Zionism as the material and spiritual culmination of an historical idea. Fundamentalist Zionists, moreover, know that idea to be divinely true. It is the original idea of religious Zionism's prophet, Rabbi Abraham Isaac Kook:

To regard Eretz Israel as merely a tool for establishing our national unity-or even for sustaining our religion in the Diaspora by preserving its proper character and its faith, piety and observances-is a sterile notion, unworthy of the holiness of Eretz Israel....

The securing of the structure of the world ... demands the upbuilding of the Jewish nation. The building of the people and the revelation of its spirit are one and the same process; it is indispensable to the rebuilding of the shaken world, which is waiting for that supreme and unifying force to be found in the soul of the Holy Congregation of Israel. The soul of Israel is full of the spirit of God. ${ }^{138}$

Fundamentalists also now know that they are engaged in a holy war in defense of that truth. The nationalization of the memory of the Holocaust is a symbolic mobilization in the service of that war. It has transformed the backward peasant into a pagan archterrorist, and it has made terrorism the only real "culture" Palestinians stonethrowing youths could conceivably possess. This imagined culture in which "terrorism" is synonymous with "nationalism" is as empty of legitimate political and social agendas for national construction as is the actual nationalist Zionist program for the achievement of Greater Israel. In practice, this means the less substance there is in the political agenda, the greater the violence to impose it.

The lowering of violent expectations in the Palestinian national movement is perhaps the surest sign that their national consensus is not just a reproduction of the coercive forms of national organization that have alienated them. Nurtured by the belief that only political independence will undo the social and economic privation they have suffered in exile and under occupation, Palestinians have endeavored to alter and institutionalize the basis for state formation front reactive and coercive forms to 
consensual ones geared to social mobilization and construction. In addition, Palestinian views of who may be counted among the nations and where are now considerably more open textured. Consider in this light the recent comments of Fath's second-in-command and former head of Black September Salah Khalaf (Abu Iyyad):

In 1948 the Jews had come to the conclusion that the time was ripe to establish their own independent state in Palestine based on a reading of the ability and readiness of the Jewish people in Palestine and abroad to support and sustain such a state, as well as the readiness of the great powers to recognize its legitimacy... . Now, after more than 40 years, we feel that we are in a somewhat similar position... .A unitary, binational state cannot be built without the acquiescence of both communities; and if it is established by force against the will of one of the two, it cannot stand the test of time. The day may come when the Jews of Israel and the Arabs of Palestine, their mutual trust nurtured by a period of peaceful, prosperous, and cooperative coexistence, decide that their interests lie in some form of union. But unless and until that day comes, both peoples' interests would be served best if each went its separate way. $^{139}$

Yet the harder Palestinians strive to meet Eurocentric expectations of what it takes a nation to become a state, the more the centralizing logic of nationalist Zionism works to marginalize them and to convince the "free world" that such pariahs do not deserve perhaps the premier spot in the taxonomy of nation-states:

It was on America's Independence Day 14 years ago, that IDF forces rescued the hostages of a Palestinian terrorist group at Entebbe. That operation marked a turning point in the Western world's war against terrorism. Now the U.S. Administration's suspension of talks with the PLO has again signaled its dedication to the continuation of this war against antidemocratic, antipeace forces in the world. ${ }^{40}$

To the extent this strategy proves successful, the victims could well end up internalizing and inverting the ideology of violence that victimized them. It would not be the first time. The task of peace then is to stop this alternation at a lull in the conflict where each camp can recognize and tolerate the other as an abiding stranger within.

\section{NOTES}

1. Jerusalem Post, 30 March 1989.

2. N. Mandel, The Arabs and Zionism before World War I (Berkeley: University of California Press, 1976).

3. Minutes of Second Meeting of the Zionist Commission, Central Zionist Archives (CZA), Jerusalem, file Z4/483, 14 March 1918.

4. Palestinian violence against repeated propaganda by "responsible Zionists" that the country was "deserted and derelict" was perceived as a continuing cause of Britain's inability to administer its mandate peacefully (Haycraft Report, Palestine Disturbances in May, 1921 [London: HMSO, 19211, p. 57). Question

5. L. Kohn, "Proposals for the Preparation of a Memorandum on the Land

in Palestine," CZA, Jerusalem, file Z4/1260/II, November 1918.

6. Reception of Islamo-Christian Association by Inter-Allied Commission, 18

June 
1919; report by Abraham Elmaleh, CZA, Jerusalem, file L4/794, August 1919.

7. Zionist Executive to Colonial Office, CZA, Jerusalem, file Z4/10655, 1 June

1921. 8. Conversation held at Mr. Balfour's House, CZA, Jerusalem, file Z4/16055, 22 July

1921.

9. See B. Wasserstein, The British in Palestine: The Mandatory Government and the Arab-Jewish Conflict 1917-1929 (London: Royal Historical Society, 1978).

10. Minutes of the Palestine Zionist Executive, CZA Library, 21 May 1925.

11. Shaw Report, Palestine Commission on the Disturbances of August, 1929 (London: HMSO, 1930).

12. Histadrut memorandum submitted to Palestine Commission of Inquiry, December 1929, in Documents on Jewish Labour Policy in Palestine (Tel Aviv: Achdut, 1930).

13. Histadrut memorandum on the August disturbances, submitted to the British Labour Party and Socialist International, in Documents on Jewish Labour Policy in Palestine.

14. Minutes of the Jewish Agency Executive, CZA Library, November 1929.

15. Cf. Y. Porath, The PalestineArab National Movement 1929-1939 (London: Frank Cass, 1977).

16. S. Atran, "The Surrogate Colonization of Palestine, 1917-1939," American Ethnologist 16, no. 4 (November 1989): 719-744.

17. Minutes of the Jewish Agency Executive, CZA Library, 7-12 June 1938; cf. minutes of the Committee for Population Transfer, 1937-1938, CZA, Jerusalem, files S25/42 and S25/10.061.

18.5 August 1938 in D. Ben Gurion, Letters to Paula and the Children (Tel Aviv: Am Oved, 1968 [in Hebrew]).

19. Z. Jabotinsky, Writings (Jerusalem: Eri Jabotinsky, 1959 [in Hebrew]), pp. 251266.

20. London Sunday Times, 15 June 1969.

21. In Menachem Shalev, "The True Believer," Jerusalem Post, 16 December 1988.

22. The initiative came from Nayef Hawatma's Democratic Front for the Liberation of Palestine (DFLP); it was not formally adopted, however, until 1977 by the PLO's policy-determining body, the Palestine National Council (AI-Majlis al-Watani alfilastini [PNC]). In the 1970s, the DFLP was also the first PLO group to seek to enlist the support of the Israeli left and to call for Israelis born after 1948 to join them in forming a "popular democratic state." In the early 1980s the DFLP appeared willing to negotiate a peace settlement and recognize Israel as indicated by its acceptance of the Fez Plan issued at the twelfth Arab summit (9 September 1982). But it joined the PFLP in opposing the Amman Accord signed between Arafat and Jordan's King Hussein (11 February 1985) on the grounds that any peace talks with Israel based on UN resolution 242 failed to guarantee mention of the Palestinians except as refugees.

23. Le Monde, 5 May 1989.

24. L. Kadi, Political Documents of the Armed Palestinian Resistance Movement (Beirut: PLO Research Center, 1969 [in Arabic]), pp. 137-141. 25. Ha'aretz, 18 September 1989; International Herald Tribune, 11 August 1988. 
26. M. Begin, The Revolt (New York: Schuman, 1951), p. 335.

27. Occupying seven Knesset seats in all, the secular far right has two of the Government's nineteen cabinet posts, with Tsomet controlling science and energy, and Tehiya in charge of agriculture. Although Moledet has no place in the cabinet, without its two parliamentary votes the Shamir government would lose its majority (62 of 120 seats). Moledet's leader, Rehavam Ze'evi, makes his Party's support conditional on not "making mistakes like going to Cairo" for peace talks or "having elections in Judea, Samaria, and Gaza" (International Herald Tribune, 5 June 1990). Together, Shas and the NRP have eleven Knesset seats. Shas controls three cabinet positions, including the interior, while the NRP's two posts include education. Likud (along with Yitzhak Modai's allied Movement for Zionist Renewal) possesses all the remaining cabinet ministries.

28. S. Lachman, "Arab Rebellion and Terrorism in Palestine 1929-1939: The Case of Shiekh Izz al-Din al-Qassam and His Movement," in Zionism and Arabism in Palestine' and Israel, eds. E. Kedourie and S. Haim (London: Frank Cass, 1982).

29. Cf. Al-Fajr, 20 November 1981.

30. "An Open Letter to the Jews" and "An Appeal to the English Soldiers," CZA, Jerusalem, file S25/9783, 1936; cf. Palestine. Correspondence with the Palestine Arab Delegation and the Zionist Organisation, Cmd. 1700 (London: HMSO, 1922); also testimony of Hajj Amin al-Husseini before the Shaw Commission, Shaw Report, 3 December 1929.

31. Y Haim, Abandonment of Illusions: Zionist Political Attitudes Toward Palestinian Arab Nationalism (Boulder, Colo.: Westview Press, 1983).

32. Porath, Palestine Arab National Movement; A. Yasin, The Struggle of the Palestinian People Prior to the Year 1948 (Beirut: PLO Research Center, 1975 [in Arabic]); T. Bowden, The Breakdown ofPublic Security: the Case of Ireland 1916-1921 and Palestine 1936-1939 (Beverly Hills, Calif.: Sage, 1977); M. Budeiri, The Palestine Communist Party 1919-1948: Arab and Jew in the Struggle for Internationalism (London: Ithaca Press, 1979); A. Kayyali, Palestine: A Modern History (London: Croom Helm, 1978).

33. C. Tilly, From Mobilization to Revolution (Reading, Mass.: Addison-Wesley, 1978); G. Rude, The Crowd and the French Revolution (London: Oxford University Press, 1967).

34. This is not to deny that the peasant masses who sustained the revolt with their manpower and moral support were devoid of revolutionary elements as some commentators intimate (B. Morris, The Birth of the Palestinian Refugee Problem, 1947-1949 [Cambridge, Eng.: Cambridge University Press, 1987]). On the contrary, the "semiproletarianization" of the fellahin that ensued in the wake of Zionist colonization of the plains and British demands for cheap urban labor meant that they could no longer occupy a "traditional" peasant role in the political economy of the country (T. Swedennberg, "The Role of the Palestinian Peasantry in the Great Revolt (1936-1939)," in Islam, Politics, and Social Movements, eds. E. Burke and I. Lapidus [Berkeley: University of California Press, 1988]). They joined trade unions and organized sociopolitical self-aid groups that were nationally connected. These tended to sidestep local factions that were often polarized around village hamulas (loosely structured patrilineages) and haras (residential quarters). 
35. Hamas graffiti Gaza, 1989. Graffiti constitutes the most popular, evident, and sustained expression of ongoing debate about the Intifada. Ever since October 1989, the

Israeli army has had standing orders that allow masked youths caught in the acting of spreading graffiti to be shot on sight.

36. George Habash of the PFLP (Popular Front for the Liberation of Palestine), like the DFLP's Nayef Hawatma, is a Christian Arab. Although there is a legacy of PFLP support in Gaza owing to Nasser's patronage of its parent organization of the 1950s and 1960s, the Arab Nationalists' Movement (ANC), Islamic fundamentalism today is clearly in the ascendancy in the Gaza camps. One factor perhaps in the persistence of PFLP and DFLP support in West Bank camps such as Dahaisheh near Bethlehem is a greater presence and tolerance of Christians as equals, another is a greater commitment to "armed struggle" (as one Dahasheh poet put it: "you are born Fath, but grow up PFLP"). Ever since the 1988 Palestinian National Congress in Algiers, these PLO-affiliated groups have adhered to the principle of democratic pluralismin particular, to the PLO decision to work for a two-state solution to the IsraelPalestine conflict. But local elements of these groups within the Occupied Territories occasionally advertise the provisional nature of their adherence to the principle. For example, the PFLP leaflet of December 1988, which marked that organization's twenty-first anniversary, called for the rejection(narfud) of UN resolutions 242 and 338 and the intensification of armed struggle. The non-PLO Hamas, while tactically allied with the PLO when it comes to supporting one another's strike calls, allows no compromise on the principle of an Islamic republic for the whole of historic Palestine. This implies that Palestinian Christians and Jews will be treated as "protected minorities" (dhimmi) and tolerated guests of Islam. Willing adherents to schismatic offshots of Islam such as the Bahai and perhaps the Druze may be condemned to death for their apostasy.

37. Y. Sayigh, "Struggle Within, Struggle Without: the Transformation of PLO Politics since 1982," International Affairs 65 (1989): 256.

38. In 1985, two years after returning from a 15-year stay in the United States, Mubarak Awad opened the Center for the Study of Non-Violence in Jerusalem. Although alternately ignored and despised by PLO militants before the Intifada, his message of nonviolent civil disobedience became part and parcel of the Unified Command's tactics and PLO strategy (Awad himself was subsequently deported). Through Israel, many Palestinians have become keenly aware of political liberty-that is, the individuals' right to dispute, and protect her- or himself from, the state's corporate power through judicial appeal, the nongovernment press or otherwise. But Israel is not the area's only role model for the Palestine national movement particularly because state Zionism eschews equality-that is, opportunity for all to formulate the state's corporate conduct and enjoy its benefits. Because Israel is allied to the western liberal democracies, which espouse both liberty and equality, it relegates its more discriminatory activities to quasi-state institutions: for example, the Jewish National Fund, which, although integrally bound to the state administration and treasury, procures and allots land and housing for the 
exclusive benefit of the "inalienable Jewish patrimony." While largely eschewing liberty, other Middle Eastern national movements often stress social equality (in distribution of state benefits) while giving only lip-service to political equality (participation in the formation of state policy) including, Nasserites, Ba'aths, and (some) communists. By contrast, Islamic republicanists while also eschewing liberty preach both participatory democracy and social egalitarianism for the oppressed majority and "tolerance" for non-Moslem minorities. But no Middle Eastern nation offers both liberty and equality although that is what many Palestinians appear to want.

39. Compare H. Cobban, The Palestine Liberation Organization (Cambridge, Eng.: Cambridge University Press, 1984) and D. Horowitz and M. Lissak, Origins of the Israeli Polity: Palestine Under the Mandate (Chicago: University of Chicago Press, 1978). Also of interest is the fact that Palestinians seeking to cut economic ties to Israel and set up a self-sufficient economy, which initially concentrates on local food production and smallscale manufacture, frequently point to the Israeli kibbutz movement as a model.

40. M. Cohen, Zion and State (Oxford, Eng.: Basil Blackwell, 1987).

41. The Intifada has also given rise to a local leadership in the Occupied Territories whose weight in the Palestinian National Movement has been considerable. Mostly unknown to the western media, they are generally younger, and maintain a much lower public profile than such "media stars" as Bethlehem Mayor Elias Freij, Al Fajr editor Hanna Siniora, or even Faisal Husseini, the PLO's most authentic public figure in the Occupied Territories. Nevertheless, notes Bir Zeit Professor of Political Science Saleh Abdel Jawad, such "personalities" still "play an important role in the Intifada insofar as they represent the facade and can be its spokesmen (portes-paroles)- $a$ role which, for reasons of security, cannot be assumed by the true leaders of the Unified Command" S. Abdel Jawad, "L'intifada et ses dirigeants," Social Science Information 29, no. 1 (1990): 183-194.

42. In this vein, Palestinians daily target the Israeli, American, and European media to plead for dialogue with the PLO. Underlying the argument is that history teaches us that there have been almost no wars between two democracies (Edy Kaufman, Ha'aretz Magazine, 27 January 1989). Most Israelis remain unconvinced: As of April 1989 , a majority ( 53 percent) believed that the Intifada can be subdued by force, although the same number would consent to negotiations with the PLO (R. Cohen-Adler, "L'opinion israelienne face a l'intifada: reactions et contradictions,: Social Science Information 29, no. 1 [1990]: 167-182). One reason the Israeli public remains divided on peace with the Palestinians is that there has never been a consensus over whether all Israel has a moral right to all of historic Palestine including the Occupied Territories. As long as the Palestinians did not protest too strongly, the question lay dormant. But now "the only consensus is that the State of Israel should be allowed to live in peace. It's not even correct to say there's a consensus that it should be allowed to live in peace with its neighbors, because there's a serious dispute over exactly who are Israel's neighbours" (Robert Rosenberg,JerusalemPost, 23 March 1989). Indeed, following the formation of anarrowly rightist government in June 1990, only 14 percent of Israelis surveyed found it to their liking (Le Monde, 13 June 1990). 
43. E. Sanbar, "L'intifada en Palestine: quelques propositions de lecture du soulevement populaire palestinien," Palestine: memoires et territoires. Cahiers d'etudes strategiques, no. 14 (Paris: EHESS, 1989).

44. "No Case For Israel to Answer," Jerusalem Post, 10 September 1989.

45. It is noteworthy, however, that Israel has initially chosen to fight medieval Arab "terror" by tolerating and even financially supporting the more radical Palestinian groups over the more moderate ones. Thus in the late 1960s, PLO propaganda was allowed to spread as a counterweight to the readiness of most West Bank and Gaza residents to return to Jordanian rule. By the late 1970s, Israeli intelligence was encouraging Egyptian Moslem Brothers to help their local counterparts in Israel wrest control of Arab villages from the communists and to disaffect those in the Occupied Territories from the PLO (Z. Abu Amr, The Islamic Movement in the WestBank and Gaza, [Acre, Isr.: al-Aswar, 1989 [in Arabic]). Indeed, until Hamas was finally outlawed in late September 1989, persons aiding or abetting the organization could do so "legally" as long as they were not linked to seditious acts while any Israeli or Palestinian who met with the PLO was (and still is) liable to imprisonment. The rise of fundamentalism in Gaza (and to a lesser extent in the WestBank), together with the victories of the Moslem Brotherhood in Israeli-Arab villages during the last municipal elections, provides a telling case for the success of Israeli intelligence in its defense of "liberal democracy."

46. Falk cites the work of Shlomo Avineri as demonstrating the "medieval ethos" of modem Arabs. Avineri, professor of political science at the Hebrew University and former director-general of the foreign ministry, is the Israeli new left's most widely acclaimed intellectual. Recently he has cautioned against the abuse of the Holocaust motif: "The memory of the Holocaust can be preserved only if we remember what German Nazi murders did to the Jews in the 1940s" and not extend that memory to cover Catholic Polish nuns much less Palestinians ("Let's Not Lose Sight of the Meaning of the Holocaust," Jerusalem Post, 17 August 1989). Yet while neither Nazis or their lackeys, Palestinians are still prey to darker political forces of history in a way Jews are not because of social "underdevelopment' '(see S. Avineri, "Political and Social Aspects of Israeli and Palestinian Nationalism," in Nationalism: the Nature and Evolution of an Idea, ed. E. Kamenka [London: Arnold, 1976]). Avineri's application of teleological Marxism to explain Arab backwardness and failure to sustain a "progressive and radical" social movement akin to the Jewish national revolution is open to serious criticism on both theoretical and empirical grounds (cf. B. Turner, Marx and the End ofOrientalism [London: Allen and Unwin, 1978], pp. 25-32). Avinieri's "critical" reading of history also lends a tendentious flavor to his political arguments. Occasionally these place him on the side of the right; for example, during the invasion of Lebanon, he lectured to Israeli soldiers and officers that west Beirut should be conquered "by force" since "the Palestinians have always adopted the line of maximum noncompromise with Zionism and Israel." Moreover, "with the decimation of the PLO," Israel could realize the "legitimate Jewish liaison with Judea and Samaria" (Los Angeles Times 27 June 1982 and 20 August 1982; cf. Meron Benvenisti, "Letter to Professor Avineri,"Ha'aretz, 22 July 1982).

47. "End the Children's Crusade," Jerusalem Post, 3 August 1989. Falk's analysis is clearly as ethnocentric as it is ironic given the constant parade of 
adolescent Israeli "hikers" sporting semiautomatic weapons to the tune of martial chants. Consider also the socioreligious ethos of militarism within the context of the Holocaust motif:

At the Golani induction ceremony in front of the Western Wall ... each soldier, clutching a Bible, pledged his devotion to the Jewish state. For thousands of years, this Wall has absorbed the tears of Jews mourning not only the destruction of the last Temple, but all the millions killed because of one simple fact-they were Jews.... For 2000 years Jews lived as if weapons were treif [unclean and unkosher], and the resulting vulnerability made persecution possible. But finally it's clear that even a weapon, in the hands of a holy nation, can become holy. (Shlomo Riskin, Chief Rabbi of Efrat, Jerusalem Post, 2 June 1989)

48. "An open Letter to Israeli State Attorney Dorit Beinish," Al-Fajr, 31 July 1989. Innovating on the British practice of tying Palestinian Arab rebels to the front of motorized convoys during the Thawra, Israeli troops routinely lash Palestinian youths to jeeps when passing through hostile neighborhoods (cf. Michel Sela,"'Child's Play' in Gaza," Jerusalem Post 6 October 1989). According to a May 1990 report of the Swedish organization, Save the Children: "indiscriminate beating, tear gassing and shooting of children at home or just outside the house, playing in the street, sitting in the classroom or going to the store for groceries" had been responsible for the deaths of at least 159 children since the start of the Intifada. Over 50,000 children had been treated for injuries. In just one incident, a reserve officer was responsible for the injury of 69 children, mostly infants, when he shot tear gas into an UNRWA clinic. He was "disciplined" with a three-week suspended sentence (Le Monde, 17-18 June 1990).

49. To a considerable degree this polemic goes over much of the same turf examined in the "subcultures of violence" debate of the 1960s and 1970s. On the one hand, Ferracuti and company argue for inherent values in Italy's Sardinian subculture that foster violence (R. Ferracuti, R. Lazzari, and M. Wolfgang, eds., Violence in Sardinia [Rome: Bulzoni, 1970]). On the other hand, Erlanger argues against violence-generating values among young Black Americans and Chicanos (H. Erlanger, "Estrangement, Machismo and Gang Violence," Social Science Quarterly 60 (1979): 235-248. Erlanger's thesis has the advantage of linking processes of estrangement from the political system to tendencies among youth to seek meaning to their lives with their peers and not with family or organizations sponsored by the dominating society or group. Palestinian analysts stress adult support for the stonethrowers and the political solidarity of these youth with their society (Sanbar, "L'intifada en Palestine"). But there is also acknowledgement that political values are drawn principally from peers: "They tend to understand politics as black or white, good or bad, friends or enemies .... Leaders of the protesters often begin their political careers by adopting the ideology of their older brother, favorite cousin, or close school friend" (D. Kuttab,"A Profile of the Stonethrowers," Journal of Palestine Studies 17 (1988): 14-23.

50. D. Snyder and C. Tilly, "Hardship and Collective Violence in France, 1830 to 1960," Social Research 56 (1989): 263-293. Cf. T. Nardin, Violence and State: A Critique of Empirical Political Theory (Beverly Hills, Calif.: Sage, 1971).

51. J. Davies, "Toward a Theory of Revolution," American Sociological Review 27 (1962):5-19.

52. R. Shehadeh, "Occupier's Law and the Uprising, "Journal of Palestine Studies 
17: 24-37.

53. Sanbar, "L'intifada en Palestine."

54. Dan Shomron, Israeli Chief of Staff, Moged, Israel Television, 25 January 1989. 55. Ze'ev Schiff in Ha'aretz, 21 May 1990.

56. Davar, 22 May 1990. Shortly before the massacre, fundamentalist Rav Moshe Tsvi Neriah urged on his countrymen that: "This not the time to think, but the time to shoot left and right" (cited by Amos Oz at Peace Now rally, Tel Aviv, 26 May 1990). Conversely, the march organized by Hezbollah, the militant Sh'ite Party of God, called for "Muslim fury over the shedding of Palestinian blood by Zionists," which religiously requires "escalating the struggle to obliterate the Jewish state" (International Herald Tribune, 22 May 1990). Such a scenario hardly leaves room for ordinary life--only "Jewish blood" or "Arab blood."

57. As with the Temple Mount disturbances of 1928 and 1929, fears that Jewish nationalists would seek to dislodge Moslems from the holiest site in Islam outside Arabia infused the national conflict with an awesome fervor that reverberated well beyond the country. One result of the 1929 riots was the (temporary) reversal of Britain's pro-Zionist policy in favor of the emergence of an independent Arab Palestine. That policy reversal was conditioned in part by Britain's desire to maintain effective economic and strategic control of the largely Moslem Middle East. Similar considerations appear to be in play in the U.S.-sponsored United Nations condemnation of Israeli police action on the Temple Mount. Although there is as yet no indication that America will significantly alter its proIsraeli stance, efforts to sustain an anti-Iraq coalition and to secure economic and strategic control of the area could instigate movement toward a policy change.

58. Ze'ev Schiff in Ha'aretz, 9 October 1990; Wall Street Journal, 11 October 1990.

59. JerusalemPost, 9 August 1989; cf.Al-Fajr 27 September 1985; also polls reported in Al-Fajr, 4 April 1984, 13 July 1984; Meron Benvenisti in Al-Fajr, 1 November 1985; polls conducted among 15-18-year-old Israelis in successive years by the Jerusalem Van Leer Foundation since 1984.

60. Although, in principle, the Intifada's Unified Command holds that attacks upon collaborators are warranted only if the population involved in the Intifada is physically endangered by them, the spiral of violence has often led the PLO and Unified Command to turn a blind eye and even tacitly condone acts of violence against "wouldbe" betrayers of the Intifada: "Every Palestinian official who calls for stopping [the Intifada] will expose himself to our people's bullets" (Arafat, Voice of Lebanon, 2 January 1989). The dangers inherent in this position, both in terms of the Intifada's media image and the threat that such "inward" violence could lead to a disastrous replay of the Thawra, compelled the Intifada leadership to signal a warning. In late summer 1989, a Unified Command leaflet stipulated that "positive evidence must be secured, great care taken, and approval by the highest authorities obtained before an execution is carried out against an alleged collaborator or even before letters of warnings and threats are sent." But a year later, alleged collaborators and other nonconformists (women accused of promiscuity, drug dealers, and users) were still being tortured and "executed," mostly by youthful bands.

Palestinians argue that intolerance of collaboration is taking on a higher profile because Israel relies on informers to step up its war against the Intifada (cf. Jonathan 
Kuttab, "APalestinian View on 'Collaborators',"Jerusalem Post, 10 September 1989). That many of the leaders of the Unified Command initially had no police record and were unknown to Israeli security forces, magnified the danger of local informers. Moreover, according to Palestinian sources, Israel trains and arms thousands of collaborators, some of whom work in self-organized groups, checking names against "blacklists", beating demonstrators and so forth (New York Times, 23 September 1989). Israeli policy of holding Palestinians collectively responsible for individual actions, including actions against collaborators, also amplifies the objective threat of collaborators to Palestinian society and their worth to Israeli security forces (for example, 4 buildings housing 55 persons were demolished on 15 June 1990 after their proprietors were accused of attacking collaborators).

Leila Hudson considers the fact that far more Palestinians than Israelis have been killed by Palestinians as support for "the idea that the most potent and crucial of [the Intifada's] aspects is not direct confrontation with the Israeli state-a hopeless mismatch of resources and technology but a unifying of the Palestinians of the Occupied Territories into an organized political force to confront the Israelis with a token physical and economic force of a nature that could be amplified by the media into a confrontation of national claims and wills" ('"The Palestinian Intifada: The Culture of History and the Practice of Ideology," unpublished manuscript, University of Michigan, Department of Anthropology, October 1990).

61. In fall 1989 a special leaflet announcing the escalation of nonviolent civil disobedience was distributed. Because most taxes collected in the West Bank and Gaza go to paying the costs of occupation with little reinvested in social services to the Occupied Territories, Palestinians began refusing to pay the costs of their own repression. The hallowed principle of "no taxation without representation," would carry a special appeal for western democracies. So fearful was the Israeli administration of the economic and symbolic value of nonpayment of taxes that it went to extraordinary measures in an effort to crush the "tax rebellion" that originated in the village of Beit Sahur near Bethlehem. The village was put under curfew for weeks in autumn 1989 as troops cut telephone lines, rounded up scores of people, ransacked village homes and stores, seized and proceeded to auction off personal goods worth many times the value of the taxes ostensibly owed. Foreign diplomats who attempted to enter Beit Sahur at the invitation of the villagers were told the area was closed for reasons of "military security." When local Palestinian leaders called a press conference in the National-Palace Hotel in East Jerusalem to explain the program of nonviolent civil disobedience, the army sealed off the hotel and surrounding streets as a "military zone," the first such zone declared in East Jerusalem since its "unification" with the Israeli state (Jerusalem Post, 4 October 1989; Al-Fajr, 16 October 1989).

62. Although there are deep-seated political and socioeconomic divisions among Palestinians with feuding families often joining rival factions, as yet there is little of the widespread internecine violence that characterized the later stages of the Thawra. Nevertheless following installation of a narrow Israeli right-wing government and the suspension of U.S.-PLO talks in summer 1990, there was a sense of despair in the villages. Hamas denounced the PLO and Unified Command for advocating compromise with Israel as "the peace of the weak." While defending its policy, the Unified Command questioned in its own July leaflet "the benefit of raising the banner of peace" but warned 
against "fascist methods of sowing internal strife and discord" among Palestinians as the spectacle of internal violence seemed on the verge of an open fray. The spectre of the Thawra loomed large, as Faisal Husseini warned: "If we don't control ourselves and unify our ranks, and allow tribal and factional differences to act up, then we will fail ... returning to square one" (Al-Fajr, 9 July 1990).

63. Traditionally, the idea has been that those who commit violence essentially do so for practical ends, be they psychological or political (cf. H. Arendt, "On Violence," in Crisis of the Republic [New York: Harcourt, Brace, Jovanovich, 1970]). Primarily through the inspiration of Foucault, this thesis has come under critical scrutiny from several quarters. For Machiavellian notions of pragmatically rational, instrumental violence imply that ends are clearly perceived, that the moral limits on means are set as a function of those ends, and that the intrusion of existential contingencies will prove to be largely irrelevant. Yet revolution, for example, is by its very nature an open-ended quest for a new society, its "meaning" is notoriously an open-textured exercise in interpretation and its modalities of behavior are as unstable as the spread of rumor on the wings of unforeseen actions and events (cf. B. Singer, "Violence in the French Revolution: Forms of Ingestion/Forms of Expulsion," Social Research 61 (1989): 263293.

64. Yehuda Elkana in Ha'aretz, 2 March 1988.

65. "No-Nonsense Commander," Jerusalem Post, 5 June 1988.

66. Louis Rene Beres, "The Real Threat of Genocide," Jerusalem Post, 5 June 1988.

67. Consider the attack by young religious settlers on the Arab village of Kifl Harith: According to one Israeli military official, these self-proclaimed "hikers" apparently "opened fire like madmen" (Ma'ariv, 31 May 1989) in what another officer declared to be "a clear provocation by the settlers" (Ha'aretz, 31 May 1989).

Nevertheless, "[s]oldiers at Kifl Harith, and in recent incidents of settler retaliation, had noted the license numbers of vehicles involved, but made no effort to arrest rioters" (Jerusalem Post, 31 May 1989). By implicitly accepting the settlers' claims that attacks against Arabs constitute "retaliation," the Israeli press and public harbor an asymmetric concept of "justice" that, for example, sentences Arabs who throw Molotov cocktails for "attempted murder" of Jews but gives suspended sentences to Jews who throw Molotov cocktails "in retaliation" against Arab motorists going to work:

Why, when Jewish Cossacks capped mayhem with murder in Kifl Harith, did soldiers write down license numbers but not bother to chase or arrest them?... The government is unlikely to bring other [Jewish] pogromists to trial. That would mean putting on trial the government's own methods. (Gershom Gorenberg in Jerusalem Post, 4 June 1989)

For some Israelis, the implications for their society are horrific:

The spectre of Jews having to fight Jews is no longer a remote nightmare and Jewish racism is rearing its ugly head.... Perhaps the most perilous message, so far, that should have caused alarm bells to ring throughout the land, was sounded ... by Rabbi Yitzhak Ginzburg, the head of Joseph Tomb's yeshiva in Nablus, who said clearly and loudly that the blood of Jews and Gentiles is not the same....He was speaking after a court hearing in which eight of his students are suspected of having committed murder, arson and attempted murder during a raid on the Arab village of Kifl Harith. (Editorial in Jerusalem Post, 4 June 1989) 
68. U. Greenberg, The Book of Denunciation and Belief (Jerusalem: Sadar, 1937 [in Hebrew]).

69. Heard on Mabat, Israeli Television, 31 October 1989.

70. See Boas Evron, "Education to Fascism and Flight," Yedioth Ahronoth, 4 March 1988. Evron has been warning for some time that with Israeli's shift to the right "the true symbol of the state is no longer the Menorah of seven candlesticks, the true symbol is the iron fist." ("Strength, Strength, Strength," Yedioth Ahronoth, 10 September 1982)

71. Jerusalem Post, 21 May 1989. According to Amnesty's 1990 report on human rights violations: "Over 260 unarmed Palestinian civilians, including children, were shot dead by Israeli forces, often in circumstances suggesting excessive use of force or deliberate killings ... in many cases the victims did not appear to be involved in-violent activities" (cited in Jerusalem Post, 11 July 1990).

72. "From Abu Jihad to Demjanuk," Yedioth Ahronoth, 4 April 1988. A graduate of the rabbinical seminary and the University of Vienna, Dr. Israel Eldad (Scheib) is perhaps the last remaining intellectual "legend" of the prestate right. His writings arguably represent the most complete historico-philosophic synthesis of the diverse trends of extreme Jewish nationalism.

73. Jerusalem Post, 2 March 1989; Jerusalem Post, 28 August 1989.

74. "We Sanction the Executioner," Hadashot, 2 October 1988.

75. H. Wasserman, "Me Nationalization of the Six Million," Politika 8 (1986): 67.

76. D. Ben Gurion, Concepts and Values (1957), cited in C. Liebman and E. Don Yehiya, "Le dilemme de la conciliation d'une culture traditionnelle et des necessities politiques. La religion civile en Israel," Pardes 11 (1990): 80.

77. D. Ben Gurion, "The Imperatives of the Jewish Revolution" (1944), in The Zionist Idea, ed. A. Hertzberg (New York: Doubleday), pp. 609-610. 78. Davar, 31 January 1964.

79. C£ E. Said, "Identity, Negation and Violence," New Left Review 171 (1988): 46-60.

80. See N. Chomsky, The Fateful Triangle: The United States, Israel and the Palestinians (London: Pluto Press, 1983), pp. 104-105.

81. Cf. H. Kissinger, The White House Years (Boston: Little, Brown, 1979). The PLO, even without communists, was simply Moscow's client.

82. Accordingly, in a quid pro quo, Israel has actively engaged in a worldwide program of counterinsurgency (especially in Latin America where Israel can maintain a lower profile than it can the United States) while the United States has generally acceded to Israeli definition and treatment of Palestinian "terrorism." Indeed, in this time of a receding sentiment of communist threat-and as the memory of the Holocaust looms larger in the American public eye than ever-any attack on Israel, whether successful or not, is considered sheer terror. Thus when PLO Executive Committee member, Mohammed Abbas, claimed responsibility for the failed attempt to land Palestinian commandos on an Israeli beach, the United States decided to suspend all contacts with the PLO on the advice of virtually the entire political and media establishment (cf. Anthony Lewis, "For Arafat and the PLO, No More Time for Fudging," International Herald Tribune, 6 June 
1990). But the Israeli army's killing of 10s, wounding of 100s, and repression of $1000 \mathrm{~s}$ during the preceding two weeks aroused only Washington's "concern."

83. Speech to cabinet on eve of invasion of Lebanon, Ha'aretz 5 June 1982.

84.1. Zertal, "Du bon usage du sovenir: les israeliens et la Shoa,"Le Debat 58 (1990): 101 .

85. After achieving statehood, Labor began to abandon its dynamic social agenda in favor of setting up a state apparatus. The statist bureaucracy was dominatedby Ashkenazi Jews of European descent, thoroughly ignoring the sentiments and aspirations of immigrating Sephardi Jews of African and Asian descent. For the emerging Sephardi majority who had suffered discrimination in Arab lands, an all too facile equation of Arab persecutors with Nazi executioners underscored a "defensive" sense of national identity that required little in the way of the kind of assertive social programming that Labor espoused. Because Labor's process of immigrant absorption had denied Sephardi immigrants the possibility of forming their own consensual basis for establishing a national identity, they more readily accommodated to the political and religious agendas of the hitherto marginalized Ashkenazi nationalist and ultraorthodox movements.

86. Z. Jabotinsky, "State Zionism-The Revisionist Viewpoint," in Parties in Zionism (New York: Zionist Organization of America, 1957), p. 13.

87. M. Capra, "Beer and Olive Oil, "Ma'ariv weekly supplement, 27 November 1987; see also Eitan's remarks in New York Times, 21 October 1982.

88. For example, "Last night soldiers shot dead a masked youth who painted slogans in Hebron ... shooting him in the back of the head at close range .... According to military sources ... masked youths ... had tried to 'incite the population"' ("Masked Youths Shot Dead in West Bank," Jerusalem Post 15 October 1989). The army considers youths (usually) between 15 and 19 years old who hide their faces under kufyahs as those who direct the stonethrowing of younger children (Kuttab, "Profile of the Stone Throwers," p. 19) and take the lead in enforcing strikes and assaulting "collaborators" (Joel Greenberg, ','Masked youths are Fair Game," Jerusalem Post, 28 August 1989). But the army may now kill adolescents who cover their faces simply on the suspicion that they are "inciting the population."

89. Cf. M. Taussig, Shamanism, Colonialism, A Study in Terror and Healing and the Wild Man (Chicago: University of Chicago Press, 1987).

90. Al-Fajr, 16 January 1989; Jerusalem Post, 19 May 1989. 91. International Herald Tribune, 27-28 May 1989.

92. Houston Chronicle, 30 May 1989.

93. Washington Post, 27 May 1989.

94. Jerusalem Post, 26 May 1989. In their otherwise sober analysis of the Intifada, Israeli journalists Ze'ev Schiff and Ehud Ya'ari take heart that "the struggle to maintain the IDF's moral stature was joined by the army's judicial system. The military courts simply did not allow soldiers to get away with excesses" (Z. Schiff and E. Ya'ari, Intifada: the Palestinian Uprising-Israel's Third Front [New York: Simon and Schuster, 1990], p. 154). On 6 October 1989, in yet another trial of the Givati, the Jerusalem Post reported that soldiers thought they were obeying the defense minister's orders:

Platoon commander Lt. (Segen) Yair Polit said he received instructions not to arrest rioters because there was no room for them in the detention centres at that time. It was understood that the soldiers were ... to pursue rioters into houses, drag them out and remove them at a good distance and then break 
their limbs and release them.

The fact that Palestinians died from such beatings was not at issue since hasty burial by the army before an autopsy could be performed disallowed military prosecutors from charging the defendants with "causing death."

95. AI-Fajr, 10 May 1981, 25 February 1983, 16 September 1983, 15 February 1984.

96. M. Zuckerman, "Israel and the Holocaust," Telos 78 (1988-1989): 43-54.

97. Palestinian moderates who in their great majority deny that Jewish preoccupation with the Holocaust is of any relevance to them might consider that the moral perceptions underlying behavior of human beings toward one another are often less than wholly rational and that fruitful political negotiations often require a psychiatric temperament. To simply say "the Jews are obsessed" or "it is not our affair" hardly speaks to the real or imagined concerns that must be dealt with in any peace negotiation.

98. Still, for many Israelis, the memory of the Holocaust-whatever else it may beis a memory of innocent human suffering and of a deeply personal collective tragedy. For this reason, the moral imperative that sustains the Israeli "structure of violence" among the dwindling majority of the Israelis has yet little of the abstract Kantian character of a categorical "moral duty" that could ultimately carry it beyond human compassion to brutal slaughter as happened when the Nazis expelled the Jew from the category "human" and dutifully steeled themselves "not to show the slightest trace of emotion" in purging and racially purifying humanity (Rudolph Hoess cited in J. Halberstam, "From Kant to Auschwitz," Social Theory and Practice 14 (1988): 41-54).

99. As such, Jewish chauvinistic messianism "is a distinct variant of European conservative nationalism with its mystical overtones that had emerged as a reaction to the French Revolution and its aftermath" (Y. Shavit, Jabotinsky and the

RevisionistMovement 1925-1948 [London: Frank Cass, 1988], p. 141). Like America's Christian right, Zionist ultranationalism believes the state's founding fathers were betrayed by pluralistic democracy and godless government technocrats: "While the Israeli right wing extremists are obviously not antisemitic as most Christian radical right groups are, they display many xenophobic features and express, on occasion, clear ideas of ethnic discrimination and Social Darwinism" as well as "militarism, ethnocentrism and religiosity" (E. Sprmzak, The Emergence of the Israeli Radical Right: Ideas, Politics, Religion and Violence [New York: Oxford University Press, forthcoming]).

100. Eldad in Ha'arez, 1 August 1988.

101. E. Sprinzak, Emergence of the Israeli Radical Right; cf. E. Sprinzak, Gush Emunim: The Politics of Zionist Fundamentalism in Israel (New York: American Jewish Committee, 1986), p. 2.

102. Indeed, in defying and eventually overcoming successive government bans on settlement in the Occupied Territories, Gush Emunim activists avowedly take their lead from the illegal paramilitary "tower and stockade" (homah u migdal) settlements, which Labor "pioneers" (halutzim) erected during the Arab revolt in order to "create facts on the ground" that would force Britain to cede to Jewish territorial aspirations (see E. Orren, Settlement Amid Struggles: the Pre-State Strategy of Settlement [Jerusalem: Yad Izhak Ben-Zvi, 1978(in hebrew)]; cf. interview with Dr. Yosef Dreizin, Nekuda no. 68 [13 January 1984]). Only it is Israel's army-not a foreign power -that Gush means to finesse. 
103. I. Lustick, For the Land and the Lord: Jewish Fundamentalism in Israel (New York: Council on Foreign Relations, 1988), p. 77.

104. "Gush Emunim Extends Hand for Peace to Jericho," Jerusalem Post International, 9 May 1987.

105. M. Dayan, A New Map: Other Relationships (Tel Aviv: Ma'ariv, 1969).

106. Cf. LIM ideologue Eleazar Livneh, Crisis of Western Civilization (Tel Aviv: Schoken, 1972, [in Hebrew]).

107. Ephraim Ben Haim, "Only Settlement Will Stop Munich," Zot Ha'aretz, no. 175, (15 October 1974).

108. Ma'ariv, 23 September 1978, 6 December 1978.

109. Although Gush activists comprise no more than 20 percent of the settler population, they control nearly all aspects of security, economy, and politics in the Occupied Territories. They have appropriated for themselves nearly the same amount of scarce water, and twice the electricity, as has the Arab population, which outnumbers them 10 to 1. In 1978, Israeli Chief of Staff Raphael (Raful) Eitan, a Gush sympathizer, gave the first Gush communities responsibility for security and defense in the Occupied Territories. Through control of the Council of Settlement of Judea, Samaria, and Gaza (Moetzet Yesha), these former illegal "squatters" became government functionaries with huge budgets and enormous political and military power (M. Benvenisti, 1986 Report: Demographic, Economic, Legal, Social andPoliticalDevelopment in the WestBank [Jerusalem: Jerusalem Post, West Bank Data Project, 1986]). In addition, their control of the educational system in the Occupied Territories virtually assures continuing support for the Gush "ministate" among the settler population: The religious educational system in general and the Merkaz Harav school of Gush's spiritual guide, Rav Yehuda Tsvi Kook in particular has bred a far more ideologically committed succession than the deideologized and declining state school system.

110. As a young American member of the Revisionist youth movement, Betar, Kahane admired Jabotinsky, Begin, and especially David Raziel. Raziel, the Irgun's first commander, rejected the policy of "restraint" (havgalah) practiced by Labor's military underground, Hagannah, and instead advocated the use of terror and massive retaliation against civilians during the Arab revolt in 1937. After a stint as an FBI informer, infiltrating the radical American Christian right's John Birch Society, Kahane founded the Jewish Defense League (JDL) in New York in 1968. Its vigilante actions against "antisemites," including Jews who dealt with the Soviet Union, eventually led the FBI to arrest Kahane for possession of an illegal arsenal. In 1971 he came to Israel, and soon began agitating against a group of Blacks who had settled in the Israeli development town of Dimona claiming to be Jews. In 1972, he initiated the call for a peaceful transfer of the Arab population of Israel and the Occupied Territories. By 1974, however, he was promoting "(Jewish) Terrorism Against (Arab) Terror (TNT) (Y. Kotler, Heil Kahane [New York: Adam Books, 1986]). At first, his political party, Kach (Thus), appealed mainly to those disaffected souls on the margins of society, but it grew to include a large following among the youth of poor urban neighborhoods and development towns. Kahane was held under administrative detention for six months in 1980 after a plot to blow up the Al-Aqsa Mosque on Jerusalem's Temple Mount (Harem esh-Sherif) was uncovered involving two soldiers linked to Kach and Gush Emunim. Elected to the Knesset in 1984, he was subsequently banned from running for his "antidemocratic" 
and"racist" platform. Still many of his basic innovations in the use of the Holocaust motif to attack "western civilization," to call for the forceful eviction of the Arabs, and to justify physical and psychological terror against Arabs have become the standard fare of many in Gush and the parliamentary radical right. Other proposals, such as capital punishment for gentiles having sexual intercourse with Jews, yet lie beyond the pale.

Kahane came to preach divine redemption only after settling in Israel. But his messianic calling diverges from the Gush "mainstream" in focusing less on reclamation of the land and more on Israel's fight against the world. Israel, he says, was created by God after the Holocaust because the Lord Almighty was fed up with the way Gentiles treated His chosen people thus "desecrating His Name" (Hillul Hashem). Israel, in fact, is the "iron fist" God intends to use to beat down the Gentiles for their sacrilege "with vengeance at the proper time ... in order to show that there is a judge and there is justice in the world" against a system "in which all the ugliness and obscenity of animal hedonism and bestial selfishness can be given free reign in order to enslave and then destroy the special Divine image that was given to man" (cited in Sprinzak, Emergence of the Israeli Radical Right). His "Museum for Future Holocaust" in Jerusalem documents the world's plans for final annihilation of the Jews. Only a "sanctified" Israel led by Meir Kahane, it appears, can ward off the danger.

111. The plot to destroy the Dome of the Rock came out during interrogation. Planned between 1978 and 1982 with an abundant supply of stolen munitions, it involved a ranking Israeli army demolitions expert and several respected Gush activists. Action was postponed owing to an absence of clearcut approval from Gush religious authorities (Sprinzak, Emergence of the Israeli Radical Right).

112. Yedioth Ahronot, 30 April 1984.

113. Removal of the Arab population of Greater Israel was already favored by the overwhelming majority (64 percent) of West Bank rabbis on the eve of the Intifada (Rabbi Israel Rosen, "YeshaRabbis: To Encourage Arab Emigration, "Nekuda, no. 115 [November 1987]). Note, however, that Gush militants generally follow the injunctions of Rav Kook to implement policy through the institutions of the state: "the State of Israel, and all its institutions, just like her sky, land and fruits are holy" (Rabbi Moshe Levinger, "They are Holy," Nekuda, no. 89 [7 July 1985]). That of course requires a conscientious effort to recast those institutions-especially the military-in the image of Gush.

114. Lustick, For the Land and the Lord, p. 111.

115. In the Knesset, several influential politicians of the Israeli radical right make no significant use of messianic or fundamentalist notions of redemption and sanctification to justify the settlement of Palestine and the removal of its Arabs. Among nonfundamentalist Gush sympathizers in Parliament are Minister of Science Yuval Ne'eman, leader of Tehiya;(General-res.) Minister of Agriculture Raphael Eitan who split from Tehiya in an argument with Geula Cohen (Tehiya's quasi-messianic second in command) to form Tsomet; Yair Sprinzak, son of Israel's first Speaker of the Knesset, who left Tehiya to join (General-res.) Rehavam Ze'evi's Moledet; and the Likud "troika"-Housing Minister Ariel Sharon, Treasury Minister Yitzhak Modai, and Foreign Minister David Levy. Although these secular Gush sympathizers do occasionally appeal to Israel's transcendental geopolitical "mission" in the world, their arguments are usually couched in the apparently rational discourse of "national security" (cf. Y. Ne'eman, The Policy of Open Eyes [Tel Aviv-Ramat Aviv" Revivim, 1974] [in 
Hebrew]). They thus help to blunt Gush's increasingly vitriolic propaganda and confrontation with the army and the Arabs so as to allow Gush to proceed with its settlement program without alienating the general Israel public.

116. Until the emergence of Gush as the first religiously oriented movement since the Jewish enlightenment (haskalah) to mobilize its flock in favor of a definite political agenda, fundamentalism maintained a rather low profile in Israeli politics. Gush's parent group the National Religious Party, although religiously orthodox and Zionist, generally restricted its political ambitions to the more parochial tasks of gaining important concessions in education, finance, and housing for its adherents. In this, NRP resembles those politicoreligious formations that are ultraorthodox and non-Zionist including the Hassidic movement, Agudat Yisrael (5 seats), the anti-Hassidic (oi'Lithuanian") Degel ha-Torah (2 seats), and Degel's Sephardi offshoot, Shas (6 seats).

117. In this vein, following the massacres in the aftermath of the 1982 Lebanese war at Sabra and Shatila, Gush Emunim published a statement describing the war as a "great act of sanctification of God's name" through which Israel was carrying out its "responsibility to act to the limits of its ability to destroy the foundations of evil in the entire world" (in Ma'ariv, 3 October 1982). Apart from the general goal of saving humanity from itself, the immediate aim at the time was to lay a moral claim to Lebanon as an integral part of the land of Israel that had belonged to the biblical tribes of Asher and Naftali.

118. See Joel Rebibo, "The 'Commandment' to Conquer the Land," Jerusalem Post, 18 August 1989.

119. "The Holy Land and the Value of Life," Jerusalem Post, 6 October 1989. Indeed so extreme may be the fundamentalist preference of land over life that Israeli intelligence reported information indicating that settlers of the Arieh branch of the Tehiya party staged stone-throwing and gasoline attacks on Israeli cars "to incite settlers and draw attention to security problems in the West Bank" (Jerusalem Post, 26 September 1989).

120. Gush Emunim pamphlet, "A Movement for the Rejuvenation of Zionist Fulfillment," no date.

121.1. Eldad, The Jewish Revolution: Jewish Statehood (New York: Shengold, 1971), p. 56.

122. Tehiya activist Ephraim Ben Haim, cited in T. Raanan, Gush Emunim (Tel Aviv: Sifriat Poalim, 1980), pp. 216-217.

123. After learning of the 1982 massacres at the Sabra and Shatila refugee camps in Beirut, Likud founder and then Israeli Prime Minister Menachem Begin dismissed the world outcry against Israeli complicity in the horror with the easy disclaimer: "goyim [gentiles] kill goyim and they come to blame the Jews."

124. When Israel needed American support in the 1982 Lebanese war, Mordecai Nisan, who teaches (mostly American students) Middle East politics at the Hebrew University's School for Overseas Students, argued that "America and Israel represent the 'chosen' societies that carry the most noble dreams of civilization" (M. Nisan, American Middle East Foreign Policy [Montreal: Dawn, 1982], p. 70). But in autumn 1989 with America apparently supporting Egypt's proposal for an Israeli-Palestinian dialogue Nisan launched into an harangue against American's superficial, "Hollywood" politics. Washington's advocacy of "Palestinian national rights" amounted to no more than "apple- 
pie liberalism" and the idea of Arab-Israeli peace was merely another pie-in-the-sky "Utopia." As for the Egyptians, their aim was clear: to reestablish the hegemony of their medieval caliphate over the area between the Nile and the Euphrates (Nisan in Jerusalem Post, 27 September 1989).

125. "Platform," Tehiya-Tsomet election pamphlet, 1984, cited in Sprinzak, Emergence of the Israeli Radical Right.

126. "How we believed in Reform, Assimilation, Enlightenment, Cultural Pluralism, Liberalism, Socialism, Marxism, Participatory Democracy, Chairman Mao, Rationalism and the inherent decency of Man.... All of it died in the flame of Auschwitz" (M. Kahane, Listen World, Listen Jew [Tucson: Institute of the Jewish Idea, 1978] [in Hebrew], p. 128).

"[We need] a war of extermination against Western culture, which has brought the greatest of holocausts upon us-the Liberal holocaust" (secular fundamentalist Moshe Ben Yosef inNekuda, no.100, [11 July 1986])

127. Rabbi Menahem Fruman on Moged, Israel Television, 21 September 1989.

128. "In every generation there is an Amalek... our Amalek are the Arabs who oppose the renewal of our national existence in the land of our fathers" (Gush activist Haim Tsuria,"The Right to Hate," Nekuda, no. 15 [28 August 1980]).

"The Arabs are cancer, cancer, cancer. ... Let me become Defense Minister for two months and you will not have a single cockroach around" (Rabbi Meir Kahane in Orit Shohat, "Don't Ask Me How," Ha'aretz Magazine, 31 May 1985).

129. "Increasing isolation of the Jewish people is a blessing and not a curse and a sign of the sure coming of the final redemption" (Kahane, Listen World, Listen Jew, $p$. 140).

"The closer the world gets to the destruction of evil, the more strongly evil clings to life" (Tehiya's Rabbi Eliezer Waldman in Lustick, For the Land and the Lord, p. 143).

"The whole world is on one side, and we are on the other. If we forget our uniqueness, Esau and Ishmael will remind us with scorpions and the whip" (Rabbi Israel Sadan in A. Rubinstein, Le reve et l'histoire: le Sionisme, Israel et les Juifs [Paris: Calmann-levy, 1985], p. 41).

130. D. Yosephi, "A Humane Solution to the Demographic Problem," in The Book of the Whole Land of Israel, ed. A. Ben Ami (Tel Aviv: Freedman, 1977), p. 349.

"As we stand at the crossroads, with one direction that of glorious life and redemption, and the other the path of prior tragedy and holocaust, the choice is ours" (M. Kahane, Forty Years [Miami: Institute of the Jewish Idea, 1983] [in Hebrew], p. 66).

"MOLEDET" (The Homeland Party) will fight for Greater Zionism, for Greater Israel, for Transfer. ... Let us exterminate (na'aqur) the intifada-or it will come in the midst (tokhekhey) of Israel!" (Moledet Bulletin, no. 3, December 1988).

131. Said, "Identity and Violence," P 54.

132. Europe's acceptance of Zionism as both a practical and symbolic solution of the Jewish question is exemplified in an intriguing way by the Soviet Union's attitude. Although initially a friend and then apolitical foe of Israel, the USSR has always considered Israel a proper home for the Jewish people. Witness the fact that even during the years of enmity, the Soviet Union required Jews who wanted to emigrate to the west to go through the fiction of declaring their intention to join relatives in Israel. By contrast, Jews throughout the world generally do not regard Israel as home and many consider its 
emerging culture alien and parochial. In its positive aspect, the inclusive cosmopolitan Zionism that Herzl espoused in his Altneuland (Old-New World) has arguably failed. But Jews alienated from Israeli politics and culture also generally refuse to publicize their misgivings to non-Jews of abuses committed by Israel in the name of the Jews. Israel, it appears, is still unassailable as the last refuge against antisemitism. It is in its negative aspect then that Zionism has been largely successful among Jews and the nations of the world.

133. Theodor Herzl, Der Judenstaat (1896).

134. For Henry Cabot Lodge, Zionism's champion in Congress, "one of the great blots on the face of American civilization" was that "Palestine should be under the control of the Mohammedans" (Congressional Record, vol. 52, pt. 5, 5376,7 May 1922). A lingering ethnocentrism of this sort may well be a factor in the persistent failure of successive American administrations to concretize their "concern" over Israeli attempts to deny the Palestinians a homeland:

The Government of the US is seriously disturbed by the attitude of Israel with respect to a territorial settlement in Palestine... .In the interests of a just and equitable solution of these critical questions the United States Government, in the UN ... has supported the position that Israel should be expected to offer territorial compensation for any territorial acquisition which it expects to effect beyond the boundaries set forth in the resolution of the General Assembly of November 29, 1947. The Government of Israel has been well aware of this position and of the view that the United States Government that it is based upon elementary principles of fairness and equity." (Truman to Ben Gurion via Ambassador McDonald, 29 May 1949, Israel State Archives, Jerusalem, file FM 2444/19).

135. Weizman to Balfour, CZA, Jerusalem, file L3/310, 30 May 1918. For historian Bernard Lewis, in the Middle East, as opposed to Europe (or even China and India), there was never a "homogeneous civilization" with a "consciousness" of cultural unity over a continuous territory: "In the ancient Middle East, that unity never existed; from Antiquity to modem times, there was never such a continuity." Any semblance of national continuity today owes to an "effort that was the exclusive product of [European] strangers to the Middle East." In fact, "for the major part of the last fourteen centuries" only Islam provides continuity, and Islam "as Khomeini proclaimed more than once ... ignores frontiers." IIndeed Islamic historians emphasize that it was the Jews who introduced the pernicious doctrine of nationalism to the Middle East (B. Lewis, "La carte du Proche-Orient," Le Dgbat 78 (1990): 110-127. Historically the notion of "homeland" (watan) used by Middle East peoples thus had "no political content." "Palestine" was essentially a western concept appropriated by modem Middle Eastern westernizers. But "so alien was the idea of a territorial nation state" that Middle Easterners came to alienate themselves from their roots and blame the Israeli "dhimmi" and western "Franks" for their predicament (Lewis, The Middle East and the West [New York: Harper and Row, 19661, pp. 72, 75, 126).

By contrast, political scientist Naseer Aruri argues that "[f]or more than thirteen hundred years Palestine was inhabited by Palestinian Arabs... as a cohesive national group in their own homeland" until "Zionists succeeded in driving them into forced exile" with a "puzzling ... appearance of [seventeenth century type] settler colonialism in an era of decolonization" (N. Aruri, "Dialectics of Dispossession," in Occupation: Israel Over Palestine, ed. N. Aruri [London: Zed Books, 1984], pp. 4-5). The Palestinian newspaper Al-Fajr in its yearly calendar book further claims that Islam was itself superimposed on a 
nation of Palestinians directly descended from the ancient Philistines. Under the guise of "historical objectivity," tendentious arguments on both sides effectively serve to delegitimize the other's claim to nationhood.

136. Fourth conference of Ahdut ha'Avodah, 1924 report, p. 34.

137. Z. Jabotinsky, "The Iron Wall-We and the Arabs," in Writings (Jerusalem: Eri Jabotinsky, 1959 [in Hebrew]).

138. From "The Land of Israel" and "The War (1910-1930)," in Hertzberg, The Zionist Idea, pp. 419-423.

139. "Lowering the Sword," Foreign Policy 78 (1990): 97, 102.

140. Editorial in Jerusalem Post, 5 July 1990. Bar Ilan University political scientist Paul Eidelberg suggests, however, that should the United States persist in its "pro-Arab policy" and "illicit affair" with the PLO, then Israel should divorce its erstwhile strategic ally "just as Israeli intelligence in the Arab world has served democratic America well, so it can serve an increasingly democratic Russia" ('Towards a New Foreign Policy," Jerusalem Post, 11 July 1990).

Within the mind-set that equates resistance to a degrading occupation with terror and the occupier's law and order with democracy, William Satire blithely reassures: "Panicmongers assure us that any Likud government would crack down on the intifada and settle Soviet Jews in the disputed territories .... but a West Bank off limits to terrorists is what Likud stands for" ("Hardliners' Heyday: Don't Panic." International Herald Tribune, 12 June 1990). Of course, similar reasoning in defense of coercive territorial claims has been put to effective use before. Gush, however, subordinates the antiterror argument to a more direct one, namely, than no place on the West Bank is sacred or secure as long as it remains Judenrein. Given that Likud's governing majority depends on Gush and other ultranationalist forces that hold the ideals and checks of western democracy in contempt, Palestinians-but perhaps not only they-may well have cause to panic. They can hardly be reassured by a government seeking space for Soviet Jews in territories occupied by an army that expects these new immigrants to furnish it with new blood (see Jerusalem Post, 4 July 1990). Although Soviet Jews show little inclination to settle in the Occupied Territories and U.S. aid is conditional on not being used for settlement there, the aid that is being used to settle relatively well-trained Soviets in Israel proper frees the funds necessary for resettling working-class Israelis in the Occupied Territories. Thus massive Soviet immigration has already allowed the Jewish population there to surpass 90,000 (New York Times, 22 September 1990) and thereby to achieve virtually all of the goals set by Gush Emunim in their initial 10-year plan.

Politics \& Society 18, no. 4 (1990) 481-526. 